\title{
Living preferences of STEM workers in a high-tech business park of a peripheral region
}

Citation for published version (APA):

Hooijen, I., \& Cörvers, F. (2020). Living preferences of STEM workers in a high-tech business park of a peripheral region. Maastricht University, Graduate School of Business and Economics. GSBE Research Memoranda No. 016 https://doi.org/10.26481/umagsb.2020016

Document status and date:

Published: 19/05/2020

DOI:

10.26481/umagsb.2020016

Document Version:

Publisher's PDF, also known as Version of record

\section{Please check the document version of this publication:}

- A submitted manuscript is the version of the article upon submission and before peer-review. There can be important differences between the submitted version and the official published version of record.

People interested in the research are advised to contact the author for the final version of the publication, or visit the DOI to the publisher's website.

- The final author version and the galley proof are versions of the publication after peer review.

- The final published version features the final layout of the paper including the volume, issue and page numbers.

Link to publication

\footnotetext{
General rights rights.

- You may freely distribute the URL identifying the publication in the public portal. please follow below link for the End User Agreement:

www.umlib.nl/taverne-license

Take down policy

If you believe that this document breaches copyright please contact us at:

repository@maastrichtuniversity.nl

providing details and we will investigate your claim.
}

Copyright and moral rights for the publications made accessible in the public portal are retained by the authors and/or other copyright owners and it is a condition of accessing publications that users recognise and abide by the legal requirements associated with these

- Users may download and print one copy of any publication from the public portal for the purpose of private study or research.

- You may not further distribute the material or use it for any profit-making activity or commercial gain

If the publication is distributed under the terms of Article $25 \mathrm{fa}$ of the Dutch Copyright Act, indicated by the "Taverne" license above, 
Inge Hooijen, Frank Cörvers

Living preferences of STEM workers in a high-tech business park of a peripheral region

RM/20/016

ISSN: $2666-8807$

\section{GSBE}

Maastricht University School of Business and Economics

Graduate School of Business and Economics

\section{P.O Box 616}

NL- 6200 MD Maastricht

The Netherlands 


\title{
Living preferences of STEM workers in a high-tech business park of a peripheral region
}

\author{
Inge Hooijen ${ }^{1}$ \& Frank Cörvers ${ }^{1,2}$ \\ ${ }^{1}$ ROA/Maastricht University \& NEIMED \\ 2 Tilburg Law School/Tilburg University \& CAOP
}

\begin{abstract}
Despite the importance of STEM workers to regional economies, scientists and policymakers have a limited understanding of how to recruit this scarce target group, particularly in offering an attractive living environment. This case study uses self-reported overall life satisfaction to explore the living preferences of STEM workers employed at a high-tech business park (HTBP) in a demographically shrinking region in the southern periphery of the Netherlands. We argue that individuals' selfevaluation of life satisfaction is a proxy for their individual utility and thereby indicates the preferred features of the geographical unit in which they reside. We relate the survey data of 420 employees at the business park to the specific characteristics of the municipalities they live in, complemented by qualitative data from 32 semi-structured interviews with these workers. We conclude that the average STEM worker at the HTBP prefers to reside in places of lower extraversion, which are often characterized by a suburban lifestyle, green areas, and open spaces, including a little touch of consumer amenities.
\end{abstract}

Keywords: Living preferences, life satisfaction, STEM workers, high-tech business park, demographic shrinkage

JEL-codes: J11, O18, R11, R23, R58 


\section{INTRODUCTION}

Academic and policy interest in attracting and retaining highly skilled and talented people for one's national and regional economy has been growing. Special attention has been paid to creative and knowledge-intensive sectors (Musterd, Bontje \& Rouwendal, 2016). Sometimes, this attention is driven by the aim to revitalize regions challenged by the disappearance of old, often natural resourceintensive industries, such as mining. The disappearance of such industries has profound consequences for a region's economic structure and demographic composition, due to falling employment and demographic shrinkage. Once traditional industries become economically unviable, alternative solutions must be found and new business activities identified (Martinez-Fernandez et al., 2012; Massey, 1995). This paper explores the living preferences of people working in science, technology, engineering, and mathematics (STEM), using the case of a high-tech business park (HTBP) in a region that has undergone a long transformation period, from coal mining to biotechnology activities (Jeannet \& Schreuder, 2015). The business park is in South Limburg, a peripheral and demographically shrinking region in the southernmost part of the Netherlands.

An extensive portion of the data used in this case study was collected in a project commissioned by the municipalities ${ }^{1}$ surrounding the high-tech business park, as well as by several companies at the business park. The project aimed to better understand the living preferences of STEM workers, to learn how to attract this target group (Hooijen \& Cörvers, 2015). It furthermore supports outlining spatial policies, because the region's changing demographic composition requiresa transformation of the current living environment (Province of Limburg, 2016; Van Bussel et al., 2016). South Limburg belongs to one of the main Dutch areas facing population shrinkage, as classified by the Dutch government (Rijksoverheid, 2019), having declined in population by almost $8 \%$ between 2000 and 2017. The population loss has been naturally decreasing, with an excess of deaths over births (CBS, 2019a). In the municipalities surrounding the business park - that is, Beek, Stein, and Sittard-Geleen - the population was down 4-7\% in 2017 compared to 2000. The population aged 65 and over increased from approximately $14 \%$ to a quarter of the population between 2000 and 2017 (CBS, 2018). Due to high mortality and low birth rates, the municipalities in the region face demographic shrinkage

\footnotetext{
${ }^{1}$ The following public and private parties contributed to the project conducted by the private urban planning office buroSTUB on the living preferences of STEM workers: the municipalities of Sittard-Geleen, Beek, and Stein; Rabobank Westelijke Mijnstreek; LED2020; Sabic;Stamicarbon; Sitech; Brightlands Chemelot Campus; Holland Expat Centre South; Laudy projectontwikkeling; Royworks Makelaardij; Stimuleringsfonds Creatieve Industrie; the municipality of Venlo; and Océ (Van Bussel et al., 2016). Jointly with buroSTUB we developed the questionnaire.
} 
of the own population. In contrast, however, there was an incoming immigration surplus in $2018 .{ }^{2}$ The higher number of people moving into the municipalities than the number of people leaving could imply that the region is attractive enough for living and/or work. Although South Limburg's population is declining, its economy is growing, the HTBP being one of the main driving forces of regional economic growth (CBS, 2017). The labour force has not, however, grown the same pace, because of the demographic composition. The excess demand for STEM workers is therefore expected to increase (CBS, 2017; Bussel van et al., 2016; Hooijen \& Cörvers, 2015). Population shrinkage and economic growth can thus go hand in hand.

Much has been written about the impact of research and development and the importance of STEM workers in exploring the drivers of regional development over the past two decades. People working in these fields not only make a vital contribution to regional innovation by generating new ideas, but are also a key driver of employment growth (Winters, 2017; Musterd et al., 2016; Carnevale, Smith \& Melton, 2011; Dahl and Sorensen, 2010; Boschma \& Fritsch, 2009; Scott, 2006). In response, a growing body of literature is now focusing on the living preferencesand settlement behaviour of workers often classified as skilled, highly educated, talented, or creative. ${ }^{3}$ Such studies often treat them as a fairly homogeneous group, whereas they actually constitute a large and diverse group. The studies commonly emphasize an amenity-intensive lifestyle (e.g. with museums, theatres, restaurants) and indicate that such individuals prefer a diverse sociocultural environment (e.g. with ethnic diversity, openness, tolerance) and an urban ${ }^{4}$ living environment. We refer to such consumption and production hubs as soft locational determinants. An attractive mix of soft locational determinants is, according to

\footnotetext{
2 The total net migration increased by $22 \%$ for South Limburg comparing 2000 to 2018 . Internal migration is still the highest in absolute numbers, yet the number of immigrants settling down in the region has been strongly increasing between 2000 and 2018 (CBS, 2019a).

${ }^{3}$ Regardless of peoples' educational background, Florida (2002a, p. 328) divides the creative class into the supercreative core (computer and mathematical, architecture, engineering, life, physical, and social science, education, training, library, arts, design, entertainment, sports, and media occupations) and creative professionals (management, business and financial operations, legal, healthcare practitioners, technical, highend sales, and sales management occupations). Florida proposes that the creative class is crucial for greater regional economic prosperity. Examples of places with high shares of the creative class are Silicon Valley and Dublin. Fifteen years after The Rise of the Creative Class (2002a), Florida published The New Urban Crisis, which focuses on how creative economies generate challenges in cities, such as unaffordable housing, inequality, segregation, and gentrification. Florida (pp. 185-216) lays out solutions to these challenges, such as investing in the infrastructure for density and growth (e.g. transit and high-speed rail) and building more affordable housing for the middleclass.

${ }^{4}$ The urban milieu has become a dominant area of research in academia and policy. Most studies tend to focus on what makes urban life styles in certain areas attractive as hubs for consumption, creativity, and innovation and as residential places. For policymaking, the mainstream spatial planning approaches are based on growthoriented paradigms developed based on the experiences of successful economic areas. Such an approach is questionable in its effectiveness, because it contributes to stigmatizing areas that differ from the reference areas. An additional strategy could focus on alternatives to growth-oriented approaches (for further reading, see Kinossian, 2018; Leick and Lang, 2018).
} 
studies in the US context, key to not only local urban economic growth (Clark et al., 2002; Glaeser, Kolko \& Saiz, 2001), but also in shaping settlement behaviour (Florida, 2002a). Studies in a European context find that hard locational factors (e.g. employment opportunities) take precedence over soft locational factors as a determinant in settlement behaviour (Vossen, Sternberg \& Alfken, 2019; Musterd \& Gritsai, 2013). However, a common argument is that soft locational factors are expected to play a major role in choosing the residential location, once the work location is chosen (Sleutjes, 2013).

Studies about the living preferences of STEM workers are scarce and the results contradict the mainstream literature on settlement behaviour. Further, the analyses are often based on large geographical units, thus not accounting for intraregional characteristics. Scott (2010) provides evidence for the US and finds that engineers primarily settle in areas where the economic structure and career opportunities correspond to their occupational expertise, and that soft locational factors have no impact. Kotkin (2000) states that workers in technical occupations in the US, such as those employed in high-tech professions in Silicon Valley, prefer residing in suburban environments. Furthermore, Boterman and Bontje (2016) show that technical workers prefer a more suburban residential environment in the Netherlands.

In line with the abovementioned studies, we expect STEM workers to exhibit, on average, a preference for living in suburban envi ronments. This study uses life satisfaction as a dependent variable to explore the living preferences of STEM workers. We argue that individuals' self-evaluation of life satisfaction is a proxy for their utility and thereby indicates the features and preferences of the geographical unit in which they reside. Within this context, we analyse the role of the distances from home to work and from home to the nearest main road, the match between living preferences and actual residential behaviour, and several municipality characteristics regarding individual life satisfaction.

This study applies a mixed method approach. We use information on 25 short structured face-to-face interviews, 32 semi-structured telephone interviews, the survey data of 420 workers at the high-tech business park, and geographical data on the specific characteristics of the municipalities to better understand the relation between life satisfaction and living preferences. Using life satisfaction to explore living preferences, we find that the average STEM worker of the high-tech business park, in our case, prefers residing in a place ${ }^{5}$ with a short commuting distance, of less than 25 minutes, with a young, wealthy, and culturally diverse population, without much emphasis on production or

\footnotetext{
${ }^{5}$ We define place as a politically defined geographical cluster (e.g. urbanization level, local administrative unit) in which the perceptions, relations, and interactions of people with each other and with the environment are mutually affected (Gieryn, 2000; Massey, 1995).
} 
consumption hubs. The interview findings confirm the regression analysis results and further detail the decision-making process of STEM workers settling in a particular living environment. The results paint an image that corresponds to a suburban living environment. We refer to such an environment as places of lower extraversion. ${ }^{6}$

To our knowledge, no studies have yet explored the possible importance that life satisfaction plays in the geographical settlement pattern of a specific occupational group, such as STEM workers. However, the empirical study of life satisfaction has become a systematic scientific and policy end eavour over the last decades (e.g. Ballas \& Tranmer, 2012; Brereton, Clinch \& Ferreira, 2008; Dolan \& White, 2007). Furthermore, the link of life satisfaction to places has been explored (e.g. Kahneman, Diener \& Schwarz, 1999; Easterlin, 1974). Although these (cross)-national studies have stressed the topic of life satisfaction and place (often related to economic indicators), however, relatively few have addressed the impact of life satisfaction on a smaller geographical scale, such as at the municipality level (Bemini \& Tampieri, 2019; Ballas \& Tranmer, 2012; Morrison, 2011; Shields, Wheatley Price \& Wooden, 2009; Brereton et al., 2008; Morrison, 2007; Shields \& Wheatley Price, 2005). Our study therefore attempts to decrease the knowledge gap with respect to the impact a place and its characteristics have on individuals' life satisfaction.

This study's results are meaningful for spatial planners and policymakers in a demographically shrinking region. From the perspective of spatial planners, this study she ds light on the residential settlement behaviour and living preferences of STEM workers, emphasizing the importance of studying smaller geographical units in this context (i.e. municipalities). Further understanding of the living preferences of STEM workers could also support policymakers in developing the necessary instruments to attract this target group to specific areas and to understand the relation between life satisfaction and the characteristics of the citizens of municipalities and their living environment. The results further emphasize the need for empirical analyses to distinguish between homogeneous groups that are smaller and less diverse. Lastly, since every region is unique and has a different physical environment ${ }^{7}$ and socioeconomic and demographic composition, this study also emphasizes the options to use place-based approaches in proposing policy measures to recruit specific groups of people and offer them interesting career and living perspectives.

\footnotetext{
${ }^{6}$ Places of lower extraversion are places that are less vibrant in terms of production and consumption hubs (e.g. lower numbers of businesses and amenities, such as theatres, restaurants, and cinemas), often characterized by less dense places, such as a suburban or rural environment.

${ }^{7}$ The physical environment includes the land, air, water, plants and animals, buildings, and other infrastruc ture (Ministry of Social Development, 2003).
} 
The paper is organized as follows. Section 2 describes why life satisfaction is used to better understand living preferences and explores the literature on the relation between life satisfaction and place. From this literature, we define seven hypotheses regarding the living preferences of STEM wo rkers. Section 3 details the study area and the empirical strategy. Section 4 discusses the empirical results of both the quantitative and qualitative analyses. Section 5 concludes the paper.

\section{IDENTIFYING THE RELATION BETWEEN LIFE SATISFACTION AND PLACE}

We assume that individuals tend to maximize their individual utility function. We use life satisfaction as a proxy for individual utility and include the utility derived from the living environment. Life satisfaction ${ }^{8}$ relates to an individual's overall cognitive evaluation of satisfaction with life (Diener et al., 1999). An important assumption in our study is that an individual's level of life satisfaction living in a certain place is an empirical proxy for individual utility (Ferrer-i-Carbonell \& Frijters, 2004) and thus indicates the preferred living environment. By analysing life satisfaction, we reveal individual preferences, contributing to our understanding of the residential behaviour of individuals.

Our assumption is as follows: the difference between the benefits and costs of settling in a certain place is maximized to ensure that individual preferences are satisfied at the highest level. The choice of a particular residential location the refore becomeskey for individuals in finding a geographical area that best fits their preferences and thus fulfils their desires (Kahneman et al., 1999; Sjaastad, 1962; Tiebout, 1956). This does not suggest that all explanatory variables have an unambiguous effect on life satisfaction, since it is often an interplay of different factors that fulfilindividuals' desires.

Our analysis builds upon empirical evidence on the relation between life satisfaction and the residential settlement behaviour of individual STEM workers, given available evidence. We next formulate hypotheses on the preferences of (STEM) workers based on empirical studies on their life satisfaction, place, and settlement behaviour.

\section{Distance}

The first indicator we explore is the role of distance (to either amenities or work) in relation to life satisfaction. Research shows that the proximity (measuredin distance or travel time) of the residential location to location-specific factors affects life satisfaction. Brereton et al. (2008) find that proximity to the coast (within $2 \mathrm{~km}$ ) and an airport (within $30 \mathrm{~km}$ ) has a positive impact on life satisfaction in Ireland, whereas close proximity to a major road (less than $5 \mathrm{~km}$ ) has a negative impact. Stutzer and

\footnotetext{
${ }^{8}$ Concepts related to life satisfaction are happiness, well-being, and quality of life. Previous research suggests conceptual overlap between these concepts (see also Medvedev \& Landhuis, 2018; Veenhoven, 2012).
} 
Frey (2008), using panel data on subjective well-being in Germany, find commuting time to have a negative effect on life satisfaction. A study using a Canadian sample (Hilbrecht, Smale \& Mock, 2014) reports similar outcomes. The study by Kahneman et al. (2004) show that people derive the lowest satisfaction from commuting, compared to the satisfaction der ived from other daily activities, such as exercise or housework. Although Lorenz (2018) finds no evidence that longer commuting distances (50 km or more) lower overall life satisfaction in Germany, the author finds they do lower levels of life satisfaction within certain life domains, particularly family life and leisure. Olsson et al. (2013) find a positive association between life satisfaction and commuting time in different urban areas in Sweden. This is because it is more common to cycle or walk from home to work in Sweden, which contributes to satisfaction, rather than drive or use public transport. In addition, for the Netherlands, Boterman and Bontje (2016) show that technical workers value shorter commuting distances more than creative workers (those working in media, advertising, and social sciences jobs) and other higher-educated workers do. Frenkel, Bendit \& Kaplan (2013) find that workers employed in high-tech industries in Tel Aviv prefer residing close to their workplace. Dahl and Sorensen (2010) find that Danish technical workers value proximity to their current and previous residence and proximity to their social network more than economic factors when considering where to work. Empirical studies generally find that the impact of distance on life satisfaction is negative; for STEM workers, we expect the negative impacts of the commute distance ( $\mathrm{H} 1)$ and the distance to a major road ( $\mathrm{H} 2)$ to be stronger than average.

\section{Amenities}

We next explore the role of amenities. In recent years, a growing number of studies -especially those focusing on the American context - has suggested that amenities such as theatres, restaurants, nightlife, and entertainment play an important role in attracting people and businesses (Clark, 2002; Florida 2002a, 2002b; Glaeser , 2001). Musterd and Gritsai (2013) and Sleutjes (2013) find that soft factors such as amenities seem to be less important to knowledge workers in Europe than in the US. Sleutjes (2015) finds it plausible that amenities play a role once a work area has been chosen. For the Netherlands, Boterman and Bontje (2016) show that (urban) amenities, such as restaurants and museums, are less important for technical workers than for creative workers and other highereducated workers. Scott (2010) finds that amenities do not play a role in the location choice of engineers in the US. Therefore, we expect the number of amenities to not impact life satisfaction for STEM workers as much as for other workers (H3).

\section{Local average income}

The third indicator we focus on is the role of regional or local average income in individual life satisfaction. Growing emphasis is placed on geography as an explanatory factor for happiness and 
income. Knies, Burgess \& Propper (2007) find a positive correlation between neighbourhood incomes and subjective well-being in Germany. Their study furthermore indicates that the better off the average neighbour, the happier people are. Similar findings are reported by Clark, Westergård-Nielsen \& Kristensen (2009) using Danish data. Dittmann and Goebel (2010) furthermore show that, in Germany, life satisfaction increases with the neighbourhood's socioeconomic status. Knies (2011) finds that people who are changing residence value living in richer neighbourhoods. A potential explanation for this is that a richer neighbourhood is reflected by higher-quality services and more and diverse local amenities and visible consumer goods, such as the types of cars parked on the streets. Greater spending can also simultaneously contribute to an economically flourishing municipality. Therefore, a municipality's higher average income could its higher quality of life. As far as we know, empirical studies on the relation between average local income and life satisfaction have not differentiated between STEM and non-STEM workers. Hence, we expect life satisfaction to increase if the municipality's average income is higher for both STEM and non-STEM workers (H4).

\section{Cultural diversity}

We further explore the impact of local cultural diversity on life satisfaction. There are opposing arguments for the desirability of a diverse society. Arguments against are that diversity lowers social capital, creates different perceptions, low ers trust, and limits the possibility of speaking the language of the host country, which can increase social conflict and thus negatively impact life satisfaction. Arguments supporting diverse societies point to positive increase in social cohesion and social capital, employment, productivity, wages, and consumer utility, such as the amount of (ethnic) amenities and facilities (e.g. shops and restaurants). Therefore, culturally diverse societies can also have a positive impact on life satisfaction (Akay, Constant \& Giulietti, 2014; Longhi, 2014, Bakens, Mulder \& Nijkamp, 2013). Florida (2002b) and Florida and Gates (2001) find a positive relation between diversity (among other factors measured by the percentage of ethnic groups and homosexual people in a region) and the concentration of high-tech industries. These findings indicate that individuals with high levels of human capital (defined as having a bachelor's degree and above) are attracted to places scoring high in diversity and that regional innovation and economic growth are positively related to diversity. Although the literature on cultural diversity and life satisfaction is limited, we expect STEM workers living in areas with greatercultural diversity to have higher life satisfaction (H5).

\section{Ageing and population decline}

Alongside internal mobility, international migration, and low birth rates, demographic change has involved a rising number of the elderly. Demographic change produces complex challenges because of its socioeconomic implications. These challenges point to the structure of the working age population, local amenities and services and health and social welfare systems, as well as the 
attractiveness of a place (Organisation for Economic Co-operation and Development, or OECD, 2013, 2014). For the US, Glaeser(2016) find lower levels of self-reported well-being in cities with a declining population in 2000 than in other cities; however, individuals in these declining cities also appear to have been unhappy in the past (in 1940). In addition, Delken (2008) finds that, in Germany, whether people live in a city with a shrinking ${ }^{9}$ or a growing population does not matter for life satisfaction. Population decline and ageing are topics that have received relatively sparse attention in regional science (McCann, 2017). This also points to a gap in understanding the impact of ageing and/or a declining population on the overall life satisfaction of individuals in a certain area.

Ageing can have an impact on different aspects of society. Citizens in different life stages are likely to differ in many ways, because they might not identify with each other or could have conflicting interests. These differences could, for example, be expressed in terms of generations and political perceptions. Whereas younger generations might value political and social change and the integration of new technologies, the elderly can be more conservative. Such differences can lead to heterogeneity in the interests of younger and older citizens in a certain area and arguably push young people of working age away from areas with many retirees, to maximize their well-being elsewhere (Mannheim, 1936). Hence, we expect both STEM and non-STEM workers to have lower life satisfaction in areas with increasing numbers of elderly, that is, those past the age of retirement age (H6).

\section{Urbanization level and population density}

Studies on the effect of population density on life satisfaction show various outcomes. Florida, Mellander and Rentfrow (2013) find that denser places are correlated with lower levels of happiness, when controlling for wages. The same is true for Sørensen (2014), who, using data from the European Values Study (2008), finds higher life satisfaction among European rural dwellers than among city dwellers, regardless of living in a poorer or richer Member State. However, Shucksmith et al. (2009) find only small rural-urban differences in the quality of life in richer European countries such as Denmark, Luxembourg, and the Netherlands, slightly in favour of rural areas. With regard to STEM workers, Kotkin (2000) concludes that workers in technical occupations in the US, such as high-tech professions in Silicon Valley, prefer residing in locations other than dense urban areas. Boterman and Bontje (2016) find that technical workers in the Netherlands prefer a more suburban environment to live in, compared to other higher-educated workers, whereas workers in creative industries are more likely to opt for urban environments. We expect life satisfaction to drop more for STEM workers than fornon-STEM workers as population density or urbanity increases (H7).

\footnotetext{
9 Delken (2008) defines shrinking and growing cities, respectively, as those facing a population decrease or increase of $3 \%$ or more from 1990 to 2005.
} 


\section{METHODOLOGY AND DATA}

\subsection{Study area}

This paper is based on a study conducted on behalf of various local governments and public and private institutions in South Limburg to explore the living preferences of STEM workers. South Limburg $^{10}$ is in Limburg Province, in southeast Netherlands (see Figure 1), bordering Belgium to the southwest and Germany to the east. South Limburg is a peripheral region from a Dutch perspective, but it can be considered a central region from a European perspective. South Limburg is near several larger European cities: Brussels and Antwerp, in the west, and Düsseldorf and Cologne, in the east, are all less than $125 \mathrm{~km}$ away, compared to central areas of the Netherlands, which are over $200 \mathrm{~km}$ away.

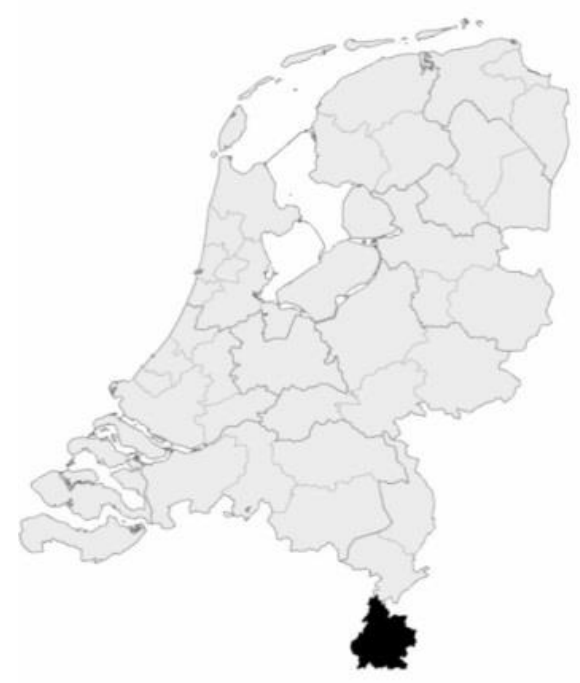

Figure 1: Location of South Limburg (NUTS-3) in the Netherlands

South Limburg was once a prosperous area servicing 12 mining sites (eight privately operated) between the beginning of the 20th century and the beginning of the 1960s (Langeweg, 2011). In 1965, the Dutch government decided to shut down the mining operations because it was no longer economical to continue. After dissolution of the coal mines, South Limburg faced the decline of its major economic sector of production and employment. A decade after the mine closures, the employment rate for South Limburg had decreased by $15 \%$, whereas it had increased by $4 \%$ for the Netherlands overall. During the same period, the population grew ${ }^{11}$ only $6 \%$ in South Limburg,

\footnotetext{
10 South Limburg is one of the 40 Dutch Nomenclature of Territorial Units for Statistics (NUTS-3), also known in the Netherlands as Coördinatiecommissie Regionaal Onderzoeksprogramma (Coordination Commission Regional Research Programme, or COROP) regions. The NUTS classification is used to divide the economic territories of the European Union to collect and produce regional statistics (Eurostat, 2019).

11 From the start of the mining industry in 1899 to a few years after the mine closures, the population in the entire province of Limburg quadrupled, growing faster than the average Dutch population. For the western
} 
compared to $13 \%$ for the entire Dutch population (Soeters, Spoormans \& Welten, 1990). South Limburg ${ }^{12}$ began facing negative population growth at the end of the 1990s. The region now belongs to one of the main Dutch areas facing population shrinkage as classified by the Dutch government (Rijksoverheid, 2019). However, demographic shrinkage does not necessarily mean economic shrinkage. For example, economic growth in South Limburg peaked in 2015 (3.6\%) and surpassed the Dutch average of $2.3 \%$. This growth has been mainly due to the industrial (no construction), energy, and manufacturing sectors ${ }^{13}$ in the western part of South Limburg (CBS, 2017). Although demand for STEM workers has therefore been increasing, the labour force has not been growing at the same pace (CBS, 2017).

Our specific area of study is a former coal mine in the western part of South Limburg. Operated by the Dutch State Mines, established in 1902, this mine has since become one of the largest ${ }^{14}$ ( 800 hectares) and most sustainable chemical sites in Europe today (Chemelot, 2018). Dutch State Mines al ready diversified into chemical activities by opening its first coke plant in 1919, decades before closing its first mining shafts. Sustainable products and materials such as lightweight materials for the automotive industry or anti-reflective coatings for solar panels are currently being devel oped at the site (Chemelot, 2018). The industry at the site strategically turned into one of the Netherlands' six important open innovation campuses, where students, researchers, and entrepreneurs from various industry firms form a community for the exchange and exploitation of knowledge. The industry firms interact with universities and local governments in a triple helix approach, which is based on the view

mining area in South Limburg, $19.5 \%$ of the population growth was due to positive net migration, and $80.5 \%$ was due to natural population increase from the end of the 19 th century to the mine closures in 1965 . The high rate of natural increase was the result of 1) high fertility rates influenced by the Catholic doctrine and 2) a relatively young population. For example, $45 \%$ of the population in the entire province was aged 20 years or bel ow in 1930 (CBS, 2017; Langeweg, 2011).

12 The extent of demographic change varies between municipalities in South Limburg. The population declined (by 4-10\%) in all 18 municipalities from 2000 to 2017 . However, the population increased in four municipalities (by less than $1 \%$ ) and remained relatively stable in four other municipalities (decreasing less than $0.05 \%$ ) between 2016 and 2017 . The majority (75\%) of the eight municipalities with an increasing or stable population size are classified as rural areas (CBS, 2018).

13 The sector is divided into mining and quarrying, manufacturing, electricity and gas supply, water supply, and waste management (CBS, 2017).

14 The industrial park counts 60 plants, 150 organizations, and 8,000 employees of 100 nationalities. Furthermore, it has $50 \mathrm{~km}$ of road, $60 \mathrm{~km}$ of rail, two la nd harbours, a rail terminal, $800 \mathrm{~km}$ of overhead el ectrical lines, and $150 \mathrm{~km}$ of sewer pipes (Chemelot, 2019). In addition, the HTBP (Brightlands Chemelot Campus) has the ambition of growing from 50 high-tech companies, 1,700 knowledge workers, and 600 students in 2015 to a minimum of 100 high-tech companies, 3,100 knowledge workers, and 1,000 students by 2023 (Chemelot, 2016). 
that collaboration between these three actors is crucial for the development towards a stronger, sustainable knowledge economy (Etzkowitz \& Leydesdorff, 1997). ${ }^{15}$

\subsection{Spatial unit of analysis and spatial policy objectives}

Municipalities ${ }^{16}$ are the spatial unit of analysis in this study. From a regional perspective, Dutch municipalities are considered relevant geographical units to analyse, since they maintain significant power in determining land-use policies (OECD, 2017). The 18 municipalities in the region of South Limburg have developed a joint view of the housing market and the spatial layout of the region called Structure Plan South Limburg. Structure Plan South Limburg is the main governmental document outlining the spatial policy objectives and the policies pursuing them. The purpose of this joint view is to expand South Limburg as a knowledge region and create an attractive living environment, including a well-functioning housing market. The main vision involves regional (housing) con solidation, which includes reprogramming the dwellings and residential areas for adaptive reuse. This reuse is determined by a combination of vacancy rates in the housing stock and the municipality's expected population development (Province of Limburg, 2016). The results of the project on the living preferences of STEM workers were used as input to outline the spatial policies in the Structure Plan South Limburg. The results are of interest for municipalities, because a changing demographic composition will require transformation of the current housing stock and living environment, such as a shift from family homes to more single-person households, homes for the elderly, and more sustainable dwellings (Van Bussel et al., 2016). Furthermore, the results are of interest for the companies at the HTBP regarding attracting STEM workers (including their partners or families) by offering an attractive living environment in addition to employment.

\subsection{Methodology and data collection}

This study employs a mixed method approach, and we complement the data from an online survey with interview data to generate multiple-sourced information. We use a mixed method approach for triangulation, because this involves the convergence, corroboration, and correspondence of the

15 The Brightlands Chemelot Campus HTBP is one of the four campuses - the others being the Brightlands Maastricht Health Campus, the Brightlands Smart Services Campus, and the Brightlands Campus Greenport Venlo - in the region under the umbrella name Brightlands. Brightlands is a joint triple helix initiative of Limburg Province, Maastricht University, Maastricht University Medical Center+, Zuyd University of Applied Sciences, and Fontys International Campus Venlo, in close partnership with leading companies in specific market areas (Brightlands, 2019). For further reading on the campus development in Limburg Province, see also Kooij (2015, pp. 73-84). Furthermore, partly financially supported by Limburg Province, Kennis -As Limburg is a collaboration between the university and the university of applied sciences in the region, aimed at strengthening the region's social and economic structure. Their projects are multidisciplinary and include different actors in, for example, trade and industry (Maastricht University, 2019).

${ }^{16}$ Municipalities are equivalent to local administrative units and are a subdivision of the NUTS-3 classification (Eurostat, 2019). 
results from the online survey and the interviews. The approach al so involves complementarity, since it seeks to elaborate, enhance, illustrate, and clarify between the qualitative and quantitative results (Greene, Caracelli \& Graham, 1989). The advantage of using both quantitative and qualitative methods is that it provides a better understanding of the relation between life satisfaction and living preferences and its interaction with the characteristics of the residential location (i.e. triangulation). Furthermore, the interviews add complementary information about employees' motivations and interpretations in the context of living preferences. They also provide greater meaning to the results of the survey data by adding contextual and detailed insights to the results of the quantitative analysis, for example, by including illustrative quotes from the interviews (O'Leary, 2010). With some exceptions (Musterd \& Gritsai, 2013; Sleutjes, 2013; Florida, 2002b), most research on living preferencesand, more specifically, on the living preferences of STEM workers is based on quantitative methods. Thus, by applying a mixed method approach, we aim to further confirm our hypotheses and gain greater comprehension of our research, includingthe empirical relevance of our m odels (Creswell \& Plano Clarck, 2011; Greene et al., 1989).

In addition, we use a sequential design that starts with explorative fieldwork, followed by the online survey. Exploratory fieldwork was conducted prior to the main data collection to inform the choice and development of the research methods and content for the subsequent empirical study (Babbie, 2008). The online survey precedes the interviews. The quantitative and qualitative components are brought together in the results, in Section 4, referred to by Morse and Niehaus (2009) as the results point of integration. The interview results are added and integrated down the results of the regression analysis. We use similar categories (distance, amenities and facilities, local average income, cultural diversity, ageing and population decline, and urbanization level and population density) for both data analyses in Section 4.

\section{Exploratory fieldwork}

In 2015 , at the campus site, buroSTUB ${ }^{17}$ conducted 25 short structured face-to-face interviews, in either English or Dutch, with employees from the high-tech business park, before implementation of the online survey. Convenience sampling is used for the face-to-face interviews, since the sample is drawn from employees close at hand at the business park (Babbie, 2008). During these interviews, the employees were asked four questions about their living environment: 1) Where do you live? 2) Why did you choose to live there? 3) How do you feel living in this region? 4) Do you miss any amenities or facilities in your living environment that you consider important?

\footnotetext{
${ }^{17}$ buroSTUB is a design agency specialized in urban design and the design of public spaces.
} 


\section{Online survey}

Next, we developed an online survey to identify the patterns of living preferences of the STEM and non-STEM workers employed in several companies at the high-tech business park. The online survey was developed in collaboration with two researchers from Maastricht University and four spatial planners. The questionnaire was tested for its overall intelligibility and to measure completion times before the survey's official distribution. Online surveys can be completed quickly and give respondents the opportunity to answer at their most convenient times (O'Leary, 2010; Babbie, 2008). The survey was randomly distributed via the communication departments of several companies at the business park by a direct email invitation that included a link to the digital questionnaire. A total of 1,533 employees received the invitation, and the survey data, collected between April 2015 and April 2016, includes information on 420 individuals (i.e. a $27 \%$ response rate).

\section{Secondary data}

In addition to the survey data, we incorporate data on specific municipality characteristics to attach greater meaning to the living environments of the respondents (see also Section 3.4). We merge our survey data with data on the district and neighbourhood maps published by Statistics Netherlands in 2015 (CBS, 2016). We consider these variables relatively consistent over time, and, therefore, the municipality's appeal - for example, land use or amenities such as bars and restaurants - is fairly steady. We thus assume these variables to be fully captured by only data from 2015 . The results of the survey data offer further input to implement the last phase of the data collection.

\section{Interviews}

In the last phase of the data collection, conducted in 2018 using a non-random sampling technique (Babbie, 2008), we approached 167 of the online survey respondents (40\% of all respondents) who indicated their willingness to participate in a follow-up survey or interview. We contacted them via the e-mail they provided in the online survey. ${ }^{18}$ Semi-structured telephone interviews were conducted with 32 individuals (19 STEM workers and 13 non-STEM workers) by the authors themselves. On average, the interviews lasted 30 minutes and were conducted in either Dutch or English. The questions in the interviews are in line with the topics covered in the questionnaire of the online survey. The interviewees were asked questions related to five topics: 1 ) individual background information, 2) dwelling and living environment, 3) their neighbourhood's demographic composition,4) the role of amenities and facilities, and 5) the role of commuting distance. Appendix 1 shows the interview guide, and Appendix 2 providesan overview of the statistics for the sample of interviewees. All the interviews

${ }^{18} \mathrm{~A}$ total of 187 individuals were invited via e-mail, and delivery to 20 of them failed. 
were recorded and transcribed by the authors. The data were organized manually and analysed following the framework noted in the literature review and hypotheses.

\subsection{Quantitative model}

We apply an ordinary least squares (OLS) regression as the main model to examine the impact of a diverse set of independent variables on the overall life satisfaction of STEM workers, relative to nonSTEM workers. This study uses life satisfaction as a measure to capture overall long-term well-being. The use of self-reported well-being can sufferfrom measurement error, since self-evaluation, moods and emotions can fluctuate over time. However, there is broad consensus in the empirical literature that the measure of self-reported life satisfaction refers to an individual's overall cognitive evaluation of satisfaction with life, rather than an immediate experience such as happiness alone (Helliwell \& Putnam, 2004; Diener, Oishi \& Lucas., 2003; Diener et al., 1999). The question used to measure life satisfaction is, 'All things considered, how satisfied are you with your life as a whole these days?' The possible responses are on a scale from zero to 10 , ranging from entirely dissatisfied to entirely satisfied. Life satisfaction scores are treated as cardinal, indicating that the distances between the different life satisfaction scores are all equal. The measure of life satisfaction is therefore assumed comparable across respondents (Ferrer-i-Carbonell \& Frijters, 2004).

The main model for each individual iin municipality $m$ is ${ }^{19}$

$$
\begin{aligned}
\mathrm{LS}_{i}= & \beta_{0}+\beta_{1} \boldsymbol{X}_{i}+ \\
& \beta_{2} \boldsymbol{A}_{i}+\beta_{3} \boldsymbol{A}_{i} *\left(\text { STEM }_{i}\right)+ \\
& \beta_{4} \boldsymbol{B}_{i m}+\beta_{5} \boldsymbol{B}_{i m} *\left(\text { STEM }_{i}\right)+ \\
& \varepsilon_{i m}
\end{aligned}
$$

where $\mathrm{LS}_{i}$, the dependent variable, denotes life satisfaction; $\beta_{0}$ is the intercept; and $\boldsymbol{X}_{i}$ is a vector of individual control variables for the following: age, age squared, gender, marital status, nationality, highest educational level, STEM occupation (see below for further details), number of children living at home, monthly home expenses, and the number of years in the home. We additionally control for extraversion (the Big Five), since research suggests this personality trait in particular is a strong predictor of life satisfaction (Schimmack et al., 2004). Furthermore, we control for self-reported satisfaction with measures of individual income, social network, and health, all shown to be robustly associated with overall life satisfaction (Bernini \& Tampieri, 2019; Morrison, 2007; Van Praag, Frijters

\footnotetext{
19 Respondents living across the border (1.9\% in Germany and 2.5\% in Belgium) were excluded from the statistical analyses because we are limited to geographical data and environmental characteristics for the Netherlands.
} 
\& Ferrer-i-Carbonella, 2003). If significant associations remain in the model after controlling for these variables that are likely to influence life satisfaction, the characteristics of municipalities could have an independent impact on life satisfaction (Morrison, 2007).

The term $\boldsymbol{A}_{i}$ denotes a vector of individual-specific place variables: commuting distance and the match between living preferences and actual residential behaviour. The distance in kilometres from home to the campus of the HTBP is calculated using the home and work postal codes. The Euclidean distances are then calculated from coordinates downloaded from Google maps. Living preferences are measured using the classical residential images method (Singelenberg, Goetgeluk \& Jansen, 2011). In this method, the respondents select an image of an urban, suburban, or rural residence resembling their residential and residential environment preferences. The measurement of actual residential behaviour is based on the urbanization level of the respondents' municipality and classified into three groups - urban (1500 or more addresses per square kilometre; e.g. the municipality of Maastricht), suburban (1000-1500 addresses per square kilometre; e.g. the municipality of Sittard-Geleen), and rural (1000 addresses or fewer per square kilometre; e.g. the municipality of Beek) - following the guidelines of Statistics Netherlands regarding the degree of urbanization (CBS, 2019b). A match is determined by similarity between the (urban, suburban, or rural) residential image and the actual residential urbanization level (urban, suburban, or rural).

The term $\boldsymbol{B}_{i m}$ indicates a vector of place-specific variables measure dat the municipal itylevel, namely, the distance from home to the nearest main road, amenities, demographic composition, and urbanization level. The distance between home and the first main road (national or provincial) is based on the home postal code and the average distance of all residents in a municipality to the nearest main road. Amenities are measured by the average number of amenities, such as restaurants, coffee houses, nightclubs, and food delivery services, within $1 \mathrm{~km}$ from home. We furthermore include the number of business establishments in a municipality. We use four indicators for the municipality's demographic composition: first, average income, calculated by using individuals' personal annual incomes; second, a measure of cultural diversity, calculated as the ratio of the number of persons with at least one parent not born in the Netherlands to the entire population in a municipality; third, an ageing variable that shows the percentage of people aged 65 and above in a municipality; and, finally, population density, which is measured as the number of inhabitants per square kilometre.

The independent variables $\boldsymbol{A}_{i}$ and $\boldsymbol{B}_{i m}$ are interacted with $S T E M_{i}$, a dummy equal to one to indicate individual $i$ works in a STEM occupation, and zero otherwise. In the online survey, the respondents 
self-selected their occupation from a dropdown list of 13 occupational fields, ${ }^{20}$ based on Dutch classification ROA-CBS 2014 (BRC 2014), derived from the 2008 International Standard Classification of Occupations (CBS, 2018). There is no standard classification of what makes up STEM occupations. We therefore refer to lower- and higher-education STEM occupations, including technical occupations, information and communication technology (ICT) professions, and researchers and research assistants. Commercial occupations, business economics and administrative occupations, service workers, and transport and logistics occupations are referred to as other occupations (Winters, 2017; European Parliament, 2015; Langdon et al., 2011).

Lastly, $\varepsilon_{i m}$ is a robust error term, clustered by municipality. This specifies that the observations could be correlated within municipalities, but independent across them (Cameron and Trivedi, 2009). Appendix 3 gives an overview of the summary and descriptive statistics. The continuous municipalityspecific variables are centred by subtracting the mean from each variable. Furthermore, the relatively small sample size and large number of independent variables gives reason to suspect that the model could suffer from multicollinearity. We therefore test for multicollinearity among the main explanatory variables (i.e. place-specific variables) in our model. The variance inflation factor value measures the extent of multicollinearity. The place-specific variables show a mean variance inflation factor of 3.39, which is not considered high enough for multicollinearity (O'Brien, 2007).

In addition, the dependent variable for life satisfaction can be treated as a categorical or an ordinal variable. This implies that the different scores can be ranked from lower to higher, as for OLS, or ordered, as for ordered probit (OP). We additionally run an OP model to control for measurement error in our dependent variable. Besides OLS methods where different scores of life satisfaction are treated as being similar, in an OP regression the dependent variable, that is, life satisfaction, is calculated as having ordered categories for which the relative differences between the values on the life satisfaction scale are assumed to be unknown. Kingdon and Knight (2007) and Ferrer-i-Carbonell and Frijters (2004) have also used OLS and OP models similarly to explain life satisfaction scores.

\footnotetext{
20 We choose to classify STEM workers based on their occupational field rather than on their field of study, because the latter does not necessarily indicate current employment in a similar field. Furthermore, we acknowledge that an even more fine-grained categorization of STEM workers could be us eful. Specific subgroups (e.g. ICT professions and res earchers) can value different residential orientations. Our sample size is, however, too limited to distinguish between subgroups of STEM workers in the empirical model.
} 


\section{Results}

\subsection{Using life satisfaction to reveal living and place preferences}

This section discusses the results of the regression models where we use life satisfaction as a dependent variable to reveal living and place preferences and tests our hypotheses. Columns (a) and (b), respectively, of Table 1 report the interaction results of the OLS and OP regressions for STEM workers. We additionally test for the impact of different values on the life satisfaction scale by presenting the marginal effects at the means (MEMs) for an OP regression in Table 2. The OP regression uses the same specification as the OLS regression. Appendix 4 reports the results of the full model.

First, for both OLS and OP regressions, we refer to the main effects on life satisfaction reported in Appendix 4. The table in Appendix 4 shows a significant negative effect for STEM workers. STEM workers are thus, on average, less satisfied with their life than non-STEM workers. To the best of our knowledge, no studies have previously explored the life satisfaction of STEM workers. Furthermore, increasing the distance from home to the nearest main road has a positive main effect on life satisfaction. Brereton et al. (2008) find opposite results in Ireland, where close proxi mity to a major road (less than $5 \mathrm{~km}$ ) impacts life satisfaction negatively. In addition, living in a suburban or rural environment relative to an urban environment negatively influences life satisfaction. This result is in contrast with Sørensen's (2014) study, which finds greater life satisfaction among European rural dwellers than among those living in urban areas. However, Shucksmith et al. (2009) find only small rural-urban differences in the quality of life in the Netherlands.

Table 1: Interaction effects on life satisfaction for OLS and OP regressions

\begin{tabular}{lll}
\hline Life satisfaction & \multicolumn{1}{c}{$\begin{array}{c}\text { OLS } \\
\text { (a) }\end{array}$} & \multicolumn{1}{c}{$\begin{array}{c}\text { OP } \\
\text { (b) }\end{array}$} \\
\hline Interaction distance & & \\
STEM worker*distance to work & -0.005 & -0.006 \\
& $(0.006)$ & $(0.007)$ \\
& $-0.722^{* * *}$ & $-0.940^{* * *}$ \\
STEM worker*distance to nearest main road & $(0.245)$ & $(0.317)$ \\
& & \\
Interaction amenities \& facilities & -0.000 & $-0.000^{*}$ \\
STEM worker*number of businesses & $(0.000)$ & $(0.000)$ \\
STEM worker*number of restaurants and bars & 0.008 & 0.035 \\
& $(0.0337)$ & $(0.0405)$ \\
Interaction demographics & & \\
STEM worker*average annual local income & $0.321^{* * *}$ & $0.427^{* * *}$ \\
& $(0.105)$ & $(0.130)$ \\
STEM worker * cultural diversity & $0.132^{* *}$ & $0.167^{* *}$ \\
\hline
\end{tabular}




\begin{tabular}{|c|c|c|}
\hline & (0.053) & $(0.065)$ \\
\hline STEM worker*people aged $>65$ & $\begin{array}{l}-0.259 * * * \\
(0.0939)\end{array}$ & $\begin{array}{l}-0.334^{* * *} \\
(0.122)\end{array}$ \\
\hline STEM worker*population density & $\begin{array}{l}0.001 \\
(0.000)\end{array}$ & $\begin{array}{l}0.001 \\
(0.000)\end{array}$ \\
\hline \multicolumn{3}{|l|}{ Interaction urbanization level (ref.: urban) } \\
\hline STEM worker*suburban & $\begin{array}{l}1.149 * * * \\
(0.399)\end{array}$ & $\begin{array}{l}1.563^{* * *} \\
(0.465)\end{array}$ \\
\hline STEM worker*rural & $\begin{array}{l}1.656^{* * *} \\
(0.575)\end{array}$ & $\begin{array}{l}2.186^{* * *} \\
(0.703)\end{array}$ \\
\hline \multicolumn{3}{|l|}{ Interaction living preferences \& actual residence } \\
\hline STEM worker*match & $\begin{array}{l}-0.064 \\
(0.229)\end{array}$ & $\begin{array}{l}-0.074 \\
(0.267)\end{array}$ \\
\hline Constant & $\begin{array}{l}3.944 * * \\
(1.698)\end{array}$ & \\
\hline $\boldsymbol{N}$ & 420 & \\
\hline$R^{2}$ - pseudo- $R^{2}$ & 0.376 & 0.164 \\
\hline $\begin{array}{l}\text { Individual control variables } \\
\text { Robust standard errors are in parentheses, and } \\
\text { coefficients shown } \\
* * * p<0.01, * * p<0.05 \text {, and } * p<0.1 \text {. }\end{array}$ & Yes & Yes \\
\hline
\end{tabular}

Next, the results for the interaction effects of STEM workers in Table 1 are consistent between the OLS method (column (a)) and the OP method (column(b)). Except for the coefficient estimated for the number of businesses, which is marginally statistically significant $(p<0.1)$ in column (b), there are no differences for the other coefficients with respect to their signs and levels of statistical significance. Furthermore, the coefficients in both columns are also of comparable magnitude. These results are generally in line with the studies of Brereton et al. (2008), Kingdon \& Knight (2007), and Ferrer-iCarbonell \& Frijters (2004), who test the robustness of the coefficients explaining life satisfaction with OP and OLS methods but find no differences with respect to the sign s or significance levels.

\section{Distance}

For the effect of commuting distance on life satisfaction, there is no difference between STEM and non-STEM workers. The distance to work has a negative effect on life satisfaction, but it is not significant. We therefore do not confirm $\mathrm{H} 1$, that commuting distance negatively impacts life satisfaction more for STEM workers. In addition, we find the distance from the home to the nearest main road to have a positive main effect of $0.342(p<0.10)$ on life satisfaction (Appendix 4 ), the OLS results in column (a) of Table 1 indicate that this effect is $-0.722(p<0.01)$ lower for STEM workers relative to all workers (i.e. compared to the main effect). A similar finding is reported in column (b) for the OP results. This result implies that STEM workers value living close to a main road more than non- 
STEM workers do. On the contrary, we expected increasing distance to the main road would have a stronger than average negative impact on life satisfaction for STEM workers. Therefore, we find evidence supporting $\mathrm{H} 2$, that life satisfaction decreases more for STEM workers than for non-STEM workers fartherfrom a main road.

\section{Amenities and facilities}

Soft locational factors, such as amenities, are not observed to play an important role in the settlement behaviour of STEM workers (Boterman \& Bontje, 2016; Scott, 2010). Only in the OP model (column (b) of Table 1) do we find a very small negative and marginally significant effect of the number of businesses on overall life satisfaction for STEM workers relative to non-STEM workers. We therefore conclude that we cannot confirm H3, which states that STEM workers attach a lower value than the average worker to amenities and facilities in their residential environment.

\section{Local average income}

The positive and statistically significant coefficient $(0.321 ; p<0.01)$ for the interaction effect of average annual income in municipalities and STEM workers indicates that a higher average income of Table 1in a municipality increases the life satisfaction of the average STEM worker (see also column (b)). Our results are in line with previous studies that find positive relations between regional income and life satisfaction (Knies, 2011; Dittmann \& Goebel, 2010; Clark et al., 2009; Knies et al., 2007); however, these studies do not focus on STEM workers. In our study, we do not find this effect for all workers (see the main effect in Appendix 4); $\mathrm{H} 4$ is therefore only confirmed for STEM workers.

\section{Cultural diversity}

We further explore the impact of local cultural diversity on life satisfaction. The OLS results indicate that life satisfaction increases by $0.132(p<0.05)$ with greater cultural diversity in a municipality. We find similar results in column (b) of Table 1 for the OP model, consistent with studies by Florida (2002b) and Florida and Gates (2001), who find a positive relation between diversity and the concentration of high-tech industries. The results also confirm H5, that is, STEM workers in a residential environment with greater cultural diversity have above-average life satisfaction. ${ }^{21}$

\section{Ageing and population decline}

Next, we address the role of the percentage of people aged 65 and above in a municipality. Greater ageing in a municipality indicates lower life satisfaction for the average STEM worker $(-0.259 ; p<0.01)$. A rising number of the elderly is one of the factors driving demographic change. Challenges due to

\footnotetext{
${ }^{21}$ Note that the group of STEM workers in our sample is slightly more culturally diver se (i.e. non-Dutch) than non-STEM workers are (see Appendix 3). This finding could be correlated with cultural diversity, since, in a culturally diverse place, there will be more resources for a non-Dutch population.
} 
demographic change can indicate not only a shortage of people in the working age population and a burden on the heal th and social welfare system, but also a low level of local amenities for the working age population, and therefore the place's lower degree of attractiveness (OECD, 2013, 2014). Our results confirm the negative impact of population ageing in a municipality on life satisfaction for STEM workers only (H6). Therefore, we confirm H6 only for STEM workers.

\section{Urbanization level and population density}

The results indicate that life satisfaction for the average STEM worker increases by $1.656(p<0.01)$ and $1.149(p<0.01)$ in a rural or suburban residence, respectively, relative to an urban environment. These effects for STEM workers contrast with the negative main effects for the average worker living in a suburban $(-0.749 ; p<0.01)$ or rural $(-0.981 ; p<0.05)$ area (see Appendix 4$)$. This result aligns with previous studies that find workers in technical occupations have above-average preferences for nonurban residential environments (Boterman and Bontje, 2016; Kotkin, 2000). This finding confirms H7, which states that life satisfaction drops more for STEM workers than for non-STEM workers as population density or urbanity increases.

\subsection{Testing for heterogeneity}

Table 2 reports the $\mathrm{MEMs}^{22}$ for the interactions to test the impact of the different values on the life satisfaction scale. The marginal outcomes of the OP regression are calculated for each value of the dependent variable. Table 2 reports the marginal results for the values of eight to 10 on the life satisfaction scale, because these were the values most STEM respondents $(70.9 \%)$ gave. Less than one-third of the scores were seven or below. See Appendix 5 for an overview of the marginal effects at all the different values measured for the dependent variable. To the best of our knowledge, no previous studies have reported the impact of different values of the life satisfaction scale separately. Most studies linking life satisfaction to place apply an OP modelling approach and do not explore the results for the different values of the life satisfaction scale (Morrison, 2011; Shields et al., 2009; Morrison, 2007; Shields \& WheatleyPrice, 2005). Brereton et al. (2008) and Kingdon and Knight (2007) report the results of both OLS and OP regressions, but do not report the results for different values.

Table 2: Results for the MEMS of the OP regression on life satisfaction for the values of eight to 10 on the life satisfaction scale.

\begin{tabular}{lccc}
\hline Life satisfaction & OP & OP & OP \\
& Value 8 & $\begin{array}{c}\text { Value } 9 \\
\text { (b) }\end{array}$ & $\begin{array}{c}\text { Value 10 } \\
\text { (c) }\end{array}$ \\
\hline Interaction distance & (a) & (b) & \\
\hline
\end{tabular}

22 We find similar results when computing average marginal effects. 


\begin{tabular}{|c|c|c|c|}
\hline STEM worker*distance & $\begin{array}{l}-0.0000 \\
(0.0002)\end{array}$ & $\begin{array}{l}-0.00224^{* * *} \\
(0.0009)\end{array}$ & $\begin{array}{l}-0.0009 * * \\
(0.0004)\end{array}$ \\
\hline STEM worker*nearest main road & $\begin{array}{l}-0.0019 \\
(0.0120)\end{array}$ & $\begin{array}{l}-0.0936^{* * *} \\
(.0288)\end{array}$ & $\begin{array}{l}-0.0405^{* * *} \\
(0.0101)\end{array}$ \\
\hline \multicolumn{4}{|l|}{ Interaction amenities \& facilities } \\
\hline STEM worker*number of businesses & $\begin{array}{l}-6.6000 \\
(0.0000)\end{array}$ & $\begin{array}{l}-0.0000^{* * *} \\
(0.0000)\end{array}$ & $\begin{array}{l}-0.0000^{* * *} \\
(0.0000)\end{array}$ \\
\hline STEM worker*number of restaurants and bars & $\begin{array}{l}0.0000 \\
(0.0003)\end{array}$ & $\begin{array}{l}0.0024 \\
(0.0053)\end{array}$ & $\begin{array}{l}0.0011 \\
(0.0022)\end{array}$ \\
\hline \multicolumn{4}{|l|}{ Interaction demographics } \\
\hline STEM worker*average annual local income & $\begin{array}{l}0.0016 \\
(0.0101)\end{array}$ & $\begin{array}{l}0.0790^{* * *} \\
(0.0239)\end{array}$ & $\begin{array}{l}0.0342^{* * *} \\
(0.0097)\end{array}$ \\
\hline STEM worker * cultural diversity & $\begin{array}{l}0.0004 \\
(0.0025)\end{array}$ & $\begin{array}{l}0.0195^{* * *} \\
(0.0049)\end{array}$ & $\begin{array}{l}0.0085^{* * *} \\
(0.0026)\end{array}$ \\
\hline STEM worker*people aged $>65$ & $\begin{array}{l}-0.0012 \\
(0.0080)\end{array}$ & $\begin{array}{l}-0.0619 * * * \\
(0.0167)\end{array}$ & $\begin{array}{l}-0.0268^{* * *} \\
(.0066)\end{array}$ \\
\hline STEM worker*population density & $\begin{array}{l}1.2100 \\
(0.0000)\end{array}$ & $\begin{array}{l}0.0000 \\
(0.0001)\end{array}$ & $\begin{array}{l}0.0000 \\
(0.0000)\end{array}$ \\
\hline \multicolumn{4}{|l|}{ Interaction urbanization level (ref.: urban) } \\
\hline STEM worker*suburban & $\begin{array}{l}0.0552 \\
(0.0644)\end{array}$ & $\begin{array}{l}0.0786 \\
(0.558)\end{array}$ & $\begin{array}{l}0.0259^{*} \\
(0.0146)\end{array}$ \\
\hline STEM worker*rural & $\begin{array}{l}0.0328 \\
(0.0439)\end{array}$ & $\begin{array}{l}0.1436 * \\
(0.0809)\end{array}$ & $\begin{array}{l}0.0612^{*} \\
(0.0352)\end{array}$ \\
\hline \multicolumn{4}{|l|}{ Interaction living preferences \& actual residence } \\
\hline STEM worker*match & $\begin{array}{l}-0.0012 \\
(0.0135)\end{array}$ & $\begin{array}{l}0.0371^{*} \\
(0.0206)\end{array}$ & $\begin{array}{l}0.0166 \\
(0.0112)\end{array}$ \\
\hline $\begin{array}{l}\text { Individual control variables } \\
\text { The MEMs for the factor levels are discrete changes } \\
\text { from the base level. Standard errors are in parentheses, } \\
\text { and } * * * p<0.01, * * p<0.05 \text {, and } * p<0.1 \text {. }\end{array}$ & Yes & Yes & Yes \\
\hline
\end{tabular}

We find a consistent pattern emerging from the marginal effects in all three columns of Table 2. First, they almost al ways have the same signs as the results in Table 1. The magnitudes of the coefficients differ from the results in Table 1, and the levels of statistical significance remain the same for the highest values, apart from the interaction of the STEM worker variable with commuting distance, urbanization level and the match between living preferences and actual residence. The coefficient for the commuting distance becomes significantly negative, indicating that increasing commuting distances lowers life satisfaction. Moreover, the statistical significance of the interaction with urbanization decreases and the match between living preferences and actual reside nce becomes positive and marginally significant in Table 2. 
The results for workers reporting life satisfaction scores of seven or below (one-third of the total sample), however, are not in line with the overall results, as shown in Appendix 5. Even though controlling for individual characteristics likely impacts overall life satisfaction (satisfaction with health, income, and social network), the resources needed to maximize one's utility differ depending on the extent to which respondents are satisfied with their overall life. Workers scoring high in overall life satisfaction could already have the resources needed to maximize their utility and, hence, external factors, such as the living environment, could start to play a different role in the utility function. Workers' preferences seem to be heterogeneous with respect to life satisfaction. Low scorers in life satisfaction are associated with longer commuting distances, less culturally diverse environments, environments with greater ageing, and a lower ave rage annual income in municipalities. These results contrast with our hypotheses. The levels of significance, however, vary depending on the value on the life satisfaction scale.

\subsection{Integrating qualitative results from interviews with quantitative} results

In this section, we report the most important interview findings and link them to the results of the quantitative analyses. This approach allows us to better grasp the role of life satisfaction in living preferences. Furthermore, through insights into the respondents' living environment, we arrive at a more nuanced understanding of the role individual-specific place variables (e.g. commuting distance and time) and place-specific variables (e.g. amenities and facilities, demographic composition) play in the living environment. The 32 interviewees were, on average, 45.6 years old (ranging from 31 to 65 years), five were female and 28 were male; 19 interviewees were STEM workers and 13 were nonSTEM workers. The majority of the workers were from the Netherlands $(N=26)$, with 20 interviewees born in the province of Limburg, followed by other European countries $(\mathrm{N}=4)$ and non-European countries $(N=2)$. See Appendix 2 for more information on the interviewees and the outcomes.

\section{Life satisfaction}

All respondents reported being satisfied with their current living environment, confirming the assumption that the current situation generally reveals the living preferences of the respondents in the online survey and the quantitative analyses. For example, the following statements were made:

Yes, I am satisfied with the living environment. I enjoy living here. If I were not satisfied, I would not live here. If I were unsatisfied, I would change it. (Female, 42 years, bachelor's degree in economics, interview 20)

I find the quality of life higher in the south of the country than in the west. It is less hectic, less busy on the road, a more spacious living environment, and larger dwellings for the same 
amount of money. Also, in terms of people, the west of the country is pretty individualistic, and here it is more social, associations and things like that. A downside is that I am further away from my family and it is a downside to me that there is no sea and beach. (Male, 51 years, master's in business economics, interview 23)

A few interviewees desired changes:

I am satisfied with my dwelling and the neighbourhood, but I would desire a more sustainable environment. For example, we still have a natural gas network. I find sustainable living very important, not only for my dwelling, but also for my neighbourhood. (Male, 51 years, bachelor's in information technology, interview 12)

I am satisfied with the living environment. With the house, I still need to fix some things, but that will come with the time, I am working on it. I don't like spending too much money on the house and things like that. (Male, 43 years, $\mathrm{PhD}$ in polymer processing, interview 9)

\section{Distance}

According to $\mathrm{H} 1$, a longer commuting distance should negatively impact life satisfaction to a greater extent for STEM workers than for non-STEM workers, which is not confirmed by the quantitative analysis. Regarding the qualitative analysis of the interview findings, the commuting time turns out to be very important for most STEM interviewees. However, the same is true for an even larger percentage of the non-STEM interviewees. The qualitative analysis of the interviews is therefore in line with the results of the quantitative analysis, so we cannotconfirm $\mathrm{H} 1$. Even though not statistically significant in the quantitative analysis, the sign of the main effect (Appendix 4) of the commute distance on life satisfaction is negative. When we integrate the interview findings into the hypothesis testing, we find that increasing the commuting distance negatively impacts life satisfaction for both STEM and non-STEM workers: 'I do find distance important, and it is getting even more important, especially because our baby will be born soon' (male, 35 years, vocational training in mechanical engineering, interview 4) and ' I find distance to work very important. In my opinion, everyone should live within cycling distance from work, which is especially important for the future environment (male, 51 years, bachelor's in information technology, interview 12 ).

According to $\mathrm{H} 2$, increasing the distance to the main road would have a greater negative impact on life satisfaction for STEM workers than for non-STEM workers, as confirmed in the quantitative analysis. The interviews did not allow us to confirm $\mathrm{H} 2$, since we find STEM workers value living close to a main road more than non-STEM workers do. This could be because it saves time travelling to work, which is supported by the interviews: 'I find it important to live close to work. Especially after a 
night shift, I do not want to drive back home for a long time' (male, 38 years, vocational training in process techniques, interview 15). Several STEM interviewees also pointed out the importance of a nearby train station: 'When I just moved here, I had no car, so the availability for public transportation was very important to me' (male, 31 years, master's in technical systems and controller, interview 14) and 'I also find it important for my children to have a train station nearby' (male, 51 years, bachelor's in chemical engineering, interview 13). Furthermore, STEM interviewees go to work by either car, bicycle, motorcycle, or public transportation, whereas non-STEM interviewees more often take the car. STEM interviewees cycle, on average, 37 minutes to work and seem to strongly value physical activity and a sustainable environment: 'I go to work by bike to stay in good condition. It saves money and it is also better for the environment.' Another STEM interviewee comesto work by car but prefers to cycle to work:

I currently go to work by car (12 minutes), but the plan is to go more often by bike. I currently moved to the northern part of the site, so that makes it a bit more difficult to come by bike. I used to work in the southern part [...] I also go to the gym in between work, so coming by bike would take a lot of time. (Male, 43 years, bachelor's in mechanical engineering, interview 1 )

Note that the high-tech business park is one of the largest ( 800 hectares) chemical sites in Europe (Chemelot, 2018). In addition, both STEM and non-STEM workers there have an average commuting time of approximately 25 minutes, regardless of the form of transportation.

\section{Amenities and facilities}

Hypothesis $\mathrm{H} 3$ states that STEM workers attach a lower value than the average worker to amenities and facilities in their residential location, which cannot be confirmed in the quantitative analysis. This result is supported by the interviewees, however. For many respondents, it is important to have basic amenities and facilities, such as a supermarket or general practitioner (GP), nearby (within a radius of 15 minutes, preferably walking or cycling distance). They indicate that it is easier to have such amenities and facilities nearby, especially when you have a full-time job or children or when you do not have a car.

Some interviewees find the availability of local amenities and services limited, which is a result of demographic change:

The main supermarket in our village closed its doors a while ago, and there is only one little supermarket left. I can imagine that if you are a bit older that you want to be in proximity to such facilities, but we actually do a lot by bike or by car. (Male, 43 years, bachelor's in mechanical engineering, interview 1 ) 
I do miss some facilities. There are not a lot of ATMs in our village, and the bank where I have my bank account does not have its office in the village anymore. Ineed to drive to a town for that. (Male, 65 years, vocational training in mechanical engineering, interview 16)

Other interviewees also indicated that the locations of amenities and facilities did not play a role in choosing their residence:

I did not consider the proximity to facilities and amenities in my location choice. We did not have children that time and you do then not really consider it. For other amenities such as restaurants, you already assume that you won't find that in a village. We never thought about that, therefore it is also less important. (Male, 43 years, bachelor's in higher laboratory education, interview 2)

In addition, about $75 \%$ of the STEM interviewees did not find it important to have urban amenities and facilities, such as museums, restaurants, and concert halls, nearby:

I do not really find it important to have a theatre, museum, or so nearby. Restaurants would be nice; we actually always need to leave the village to go out for dinner. We go to a restaurant, like, once a month approximately. (Male, 34 years, vocational training in industrial electronics, interview7)

Similar findings hold for non-STEM interviewees. There are no consistent similarities for the eight (out of 32) interviewees who did find itimportant to have urban facilities and amenities nearby. They reside in areas of different urbanization levels and differ in their marital status. They are, on average, 46 years old. The only similarities we find within the group that finds it important to have urban facilities and amenities nearby is that they have a highervocational degree or above and are Dutch:

The supermarket is in walking distance and all the other facilities and amenities are in cycling distance. I find it pleasant to have these nearby. It makes life easier, especially when you have a full-time job. Also, I find it very pleasant to have theatres and restaurants nearby. I go to the cinema, out for dinner, or to a bar at least once a week. (Male, 56 years, bachelor's in several fields, interview27)

The results of the interviews suggest that the majority of the STEM interviewees do not place much value on urban amenities and facilities. This finding is in line with previous studies that indicate that soft locational factors, such as amenities, do not play a role in the settlement behaviour of STEM workers (Boterman \& Bontje, 2016; Scott, 2010). We find, however, similar results for non-STEM 
interviewees. This result is in line with those of Sleutjes (2013), who finds that soft factors do not play a dominant role in settlement behaviour in Europe.

\section{Local average income}

Hypothesis $\mathrm{H} 4$ supposes a positive relation between local average income and life satisfaction for both STEM and non-STEM workers. The results of the quantitative analysis confirm H4 only for STEM workers. In contrast to the quantitative analysis, the qualitative analysis finds that life satisfaction increases for both STEM and non-STEM workers if the municipality's average income is higher. Based on their own reports, the interviewees all indicated they were living in an average to wealthy neighbourhood: 'If I see what the people in the street do and that they are all homeowners and have two cars per family, I would describe it as a rich environment' (male, 43 years, bachelor's in higher laboratory education, interview 2 ), and

I would describe it as a wealthy neighbourhood-well, the majority of people have a detached home [...] if I see their spending pattern, in terms of what they do or their hobbies, then they should have quite a large pension. (Male, 59 years, bachelor's in business administration, management, and safety, interview 30).

\section{Cultural diversity}

The quantitative analysis confirms H5, with above-average life satisfaction for STEM workers in a residential environment with greater cultural diversity. The interview results are in line with the results of the quantitative analysis:

Where we live, there are a lot of international people - there is Spanish and other Italians and Turkish and Chinese, and about $85 \%$ is families with young children. As far as I know, there is only one elderwoman. (Female, 35 years, PhDin biotechnology, interview 6)

It has become very diverse over the last years [...] quite a few foreigners moved into this apartment complex, especially Indians, who are often expats. They rent the place for a temporary period [...] there are also students and elderly living there, and over the last years many young families with children moved in. (Male, 53 years, PhDin chemistry, interview 19)

We find that most of the STEM interviewees lived in culturally diverse neighbourhoods. This does not hold for non-STEM interviewees: 'It is a mix of families with young children and the first residents, so elderly, let's say. Only Dutch people are living here' (male, 51 years, master's in business economics, interview 25). 


\section{Ageing and population decline}

Hypothesis $\mathrm{H} 6$ assumes a negative relation between population ageing in a municipality on life satisfaction for both STEM and non-STEM workers. In the quantitative analysis, this hypothesis was only confirmed for STEM workers. The findings from the interviews support the outcome of the quantitative analysis. Most STEM interviewees indicated they lived in a relatively young neighbourhood:

The elderly are actually leaving one by one because they are passing away. In return, quite a few young adults without children are moving to this neighbourhood because the dwellings are suitable for starters [...] it is actually a rejuvenation of the neighbourhood. (Male, 43 years, bachelor's in mechanical engineering, interview 1 )

There were only young families living here when we just moved to this street, and about $30 \%$ are still living here. Newyoungfamilies replace the families that left the street. We are actually one of the older persons living here. (Male, 53 years, bachelor's in higher Laboratory education, interview 3)

STEM interviewees appear to live more often in younger environments than non -STEM interviewees: 'The average age in our neighbourhood is around 45, 50, I would say. There are not so many children living here, which is maybe a pity for my children' (female, 46 years, bachelor's in communication and psychology, interview 21) and 'There is one younger couple living in the street and three older couples, most of them are aged 50 or over' (male, 57 years, bachelor's in senior facilitymanagement, in terview 27).

\section{Urbanization level and population density}

The quantitative analysis confirms $\mathrm{H7}$, that life satisfaction drops more for STEM workers than for nonSTEM workers as the population density or urbanity increases. The results of the qualitative analysis support these findings. The results of the interviews furthermore note that the choice of the residential environment is not made independent of one's partner. In addition, a combination of different factors contributes to overall life satisfaction. Eventhough some interviewees actually prefer rural living, this does not necessarily mean they are dissatisfied. The residences of the STEM interviewees are more or less equally distributed across the three levels of urbanization (rural, suburban, and urban). The age composition is also relatively equally divided, considering the degree of urbanization. The seven STEM interviewees residing in urban areas were, on average, 42 years old, most were in a relationship, most had a higher education, and four were non-Dutch: 'The main reason for choosing this town is there is a more internationally diverse community, and the other reason is 
for the child, because we prefer our child to go to an international school' (male, 43 years, PhD in polymer processing, interview 9).

A slightly higher percentage of STEM interviewees than non-STEM interviewees lived in urban areas. However, four STEM interviewees pointed out they would prefer more rural living instead. A mix of factors often plays a role in living preferences, such as regional familiarity, income, workplace, and the partner's living preference:

My wife prefersan urban area; she is more of a city person. We have both: we are 500 metres from the German border, which is very rural, and, on the Dutch side, we have the amen ities and facilities in walking distance of our home. (Male, 43 years, bachelor's in higher laboratory education, interview 2)

I would have preferred a village over a city, because it is quieter and more personal [...] but I think that it depends on where you come from, what you are used to. I grew up in a village and I guess that I therefore prefer to live in a village. (Female, 42 years, bachelor's in mechanical engineering, interview 11)

We are not happy in a city [...] all the noise and pollution. My wife and I grew up in the countryside. The countryside is a place to relax, we can go for a walk in the evening, we like the space around us [...] we now look into the dike, an open field, the river Meuse and into Belgium. (Male, 60years, bachelor's in higher technical training, interview 19)

In some cases, the dwelling itself is the decisive factor, and less so the municipalityor neighbourhood: 'I moved here because of the dwelling. I did not even want to move to this village. I fell in love with the dwelling, and the living environment did not play a role' (male, 57 years, bachelor's in senior facility management, interview 27). Other interviewees perceive their current urban residential location as not big: 'It is not a big city, it is a medium-sized city, let's say [...] it is the second smallest town I have every livedin (female, 35 years, PhD in biotechnology, interview 6), and 'I am from bigger cities, such as San Francisco; the town I currently live in is not big to me' (male, 34 years, PhD in chemical engineering, interview 11$).{ }^{23}$

\footnotetext{
${ }^{23}$ Most of the international STEM interviewees with PhD degrees resided in Maastricht, the capital of the province of Limburg. In Maastricht, 30\% of the population has a cultural background other than Dutch (CBS, 2019c). The interviewees with PhD degrees reported that international employees live in this city more often because either their companies' HR departments suggested they live there or the international community al ready living in this city served as a pull factor.
} 


\section{CONCLUSION}

This paper argues that an individual's evaluation of life satisfaction is related to features of the geographical unit in which theyreside. This argument is based on the assumption that the level of selfreported life satisfaction reflects a proxy for the maximization of the individual's utility function, which reveals the preferred residential environment, because individuals are expected to settle in an environment considered the most desirable and attractive. Interview findings confirm this assumption, since all the respondents reported being satisfied with their current living environment.

In view of this, using life satisfaction as a dependent variable in a regression analysis with many different explanatory variables allows us to identify living preferences. More specifically, controlling for personal characteristics, we have hypothesized that distance, municipal ity characteristics, and the degree of urbanity are likely to have an impact on individual life sati sfaction. The reference point for this study is the case of STEM workers in a HTBP in a peripheral region in the southernmost part of the Netherlands. The current study primarily explores the living preferences of those employed in STEM fields.

The qualitative and quantitative results suggest that STEM workers prefer living within a relatively short commute distance and near a main road. In this study, the majority of the STEM workers commuted less than $20 \mathrm{~km}$ and have a main road within $2 \mathrm{~km}$ of their home. We find similar results for non-STEM workers. However, the interview results reveal that non-STEM workers commute more often by car than STEM workers, who prefer to travel to work by either bicycle, car, motorcycle, or public transportation. In relation to commuting, interviews with STEM workers indicate that they strongly value physical activity and a sustainable environment. The results suggest that policymakers and planners concerned with the building environment should focus on the surroundings of the HTBP at stake.

We do not find an amenity-intensive lifestyle, involving bars, nightlife, and restaurants, to have a statistically significant impact in the quantitative analysis. The findings from the interviews also suggest that the majority of the STEM interviewees do not place much value on amenities and facilities such as museums, theatres, and restaurants. Nevertheless, most STEM interviewees reported preferencesfor basic amenities and facilities, such as supermarkets and GPs. The same holds for nonSTEM workers.

The demographic composition of a municipality one settles in seems, furthermore, to play a role in the living preferences of STEM workers. We find different results for STEM workers relative to nonSTEM workers in both the quantitative and qualitative analyses. We find STEM workers who live in 
areas with greater cultural diversity to have higher life satisfaction, and STEM workers who live in areas with greater ageing to have lower life satisfaction. Furthermore, we expected higher levels of life satisfactionfor all workers with the municipality's increasing average income. This result only holds for STEM workers in the quantitative analysis, whereas the qualitative analysis finds that all workers value living in a wealthy environment. We addi tionally note that STEM interviewees particularly care about sustainable living environments (e.g. a greener gas grid and solar panels).

Furthermore, the distributions of STEM and non-STEM workers living in either a rural, suburban or urban area are about the same. However, living in a rural or suburban instead of an urban area has a positive impact on life satisfaction for STEM workers, in contrast to the lack of such an impact for nonSTEM workers. Moreover, several interviews with STEM workers living in urban areas indicate that a more rural life is preferred. A mix of factors often plays a role in living preferences. For example, decisions with regard to living preferences are not taken independent of the workers' partners. The background, preferences, and workplaces of the partners are also relevant. In addition, regional familiarity and income play a role. Lastly, the interviews reveal that the municipality or neighbourhood is not always the decisive factor in the preferred living environment, but somet imes the dwelling itself.

Henceforth, rather than suggest that the majority of people occupied in creative and knowledgeintensive sectors prefer settling in urban areas, as much of the academic debate and policies imply, our results indicate that the ave rage STEM worker seems to prefer a less vibrant lifestyle. This finding implicitly calls for a different view of the attractiveness of different geographical areas and across different (sub)groups. We argue that a more nuanced approach is important when de veloping strategies to attract STEM workers. The urban milieu has become a dominant area of research and policy, and mainstream approaches to spatial planning are based on growth-oriented paradigms. From that perspective, shrinking rural and suburban areas often have a less positive connotation.

The findings of the quantitative and qualitative analyses emphasize that strategies to attract the average STEM worker should focus on places of lower extraversion, which are often characterized by less dense places, such as a suburban or rural environment, greenareas, and open spaces, with a little touch of consumer amenities. The residential area surrounding the HTBP is a suitable location because of its nearby green areas and daily amenities and facilities. The accessible landscape, with its greenery, tranquillity, and sports facilities, is thus a very attractive regional asset.

Furthermore, to attract STEM workers, it is important to make this group aware of existing rural and suburban residential areas. For example, human resources departments could advise their newly recruited international STEM personnel to live in these areas instead of suggesting that they live in the 
capital of the province (i.e. Maastricht). It would be relevant to give workersa broader perspective on the possibilities regarding living environments and to explicitly ask for their (previous) living preferences and experiences. This goal al so calls for strategies to attract STEM workers that go beyond employment opportunities. It is important that different companies and businesses, real estate parties, universities, and (local) governments continue working together to create an attractive living environment, a well-functioning housing market, and a stronger, sustainable knowledge economy. Accordingly, policies should capture the human atmosphere contributing to the social and economic processes that construct a particular spatial setting. ${ }^{24}$

One should not, however, generalize unduly from our findings. Every place is unique and has its own historical pathways and characteristics (Wiechmann \& Bontje, 2015; Musterd \& Gritsai, 2013). We nevertheless believe that our analyses of the experiences of STEM employees in a HTBP in a shrinking region provide a (first) direction towards place-based policies.

We have shown an association between the different characteristics of a municipality and individuals' life satisfaction. We find this association to hold particularly for high scorers in life satisfaction. Our mixed methodsstudy on living preferences in relation to life satisfaction has shown itself to be useful. We continue to find statistically significant associations between different aspects of a place and individual life satisfaction after controlling for individual characteristics known to influe nce life satisfaction. This result suggests that the characteristics of municipalities can also have an independentimpact on life satisfaction (Morrison, 2007). After all, individuals identify with their living environment (see also Massey, 1995) and, as Florida (2013) note, they derive satisfaction and emotional attachment from their places of residence. We hope this finding encourages future research on living preferences to link personal characteristics and environmental variables to life satisfaction and to test the associations for different (sub)groups and geographical areas.

\section{Acknowledgements}

The authors thank all the participants in the online survey and all the interviewees who shared their personal stories with us. We extend our gratitude to Martijn van Bussel and his colleagues from buroSTUB, as well as to Sander Dijksman, Ineke Bijlsma, Maja Ročak, and Julia Reinold for their cooperation and valuable suggestions. We are also thankful for the comments of the participants at the RSA Conference in Dublin, the ROA Conference on Human Capital and Regional Development in

\footnotetext{
${ }^{24}$ For an overview regarding suggestions for spatial strategies for this region, see Van Bussel et al. (2016, pp. 65-98).
} 
Maastricht, and the Special Session on Regional and Urban Perspectives on Individual Well-Being at the ERSA Conference in Groningen in 2017. 


\section{References}

Akay, A., Constant, A., \& Giulietti, C. (2014). The impact of immigration on the well -being of natives. Journal of Economic Behavior \& Organization, 103, 72-92. doi:10.1016/j.jebo.2014.03.024

Babbie, E. (2008). The Basics of Social Research. Belmont: Thomson Wadsworth.

Bakens, J., Mulder, P., \& Nijkamp, P. (2013). ECONOMICIMPACTS OF CULTURAL DIVERSITYIN THE NETHERLANDS: PRODUCTIVITY, UTILITY, AND SORTING. Journalof RegionalScience, 53(1), 836. doi:10.1111/jors.12012

Ballas, D., \& Tranmer, M. (2012). Happy People or Happy Places? A Multilevel Modeling Approach to the Analysis of Happiness and Well-Being. International RegionalScience Review, 35(1), 70102. doi:10.1177/0160017611403737

Bernini, C., \& Tampieri, A. (2019). Happiness in Italian cities. Regional Studies, 53 (11), 1614-1624 . doi:10.1080/00343404.2019.1597266

Boschma, R., \& Fritsch, M. (2009). Creative Class and Regional Growth: Empirical Evidence from Seven European Countries. Economic Geography, 85(4), 391-423. doi:10.1111/j.19448287.2009.01048.x

Boterman, W., \& Bontje, M. (2016). 'The' creative class does not exist. Contrasting the residential preferences of creative and technical workers in Amsterdam and Eindhoven. In S. Musterd, M. Bontje, \&J. (. Rouwendal, Skills and cities: Implications of location preferences of highly educated workers for spatial development of metropolitan areas. (pp. Part II - chapter 51 36). Oxon, New York: Routlegde.

Brereton, F., Clinch, P., \& Ferreira, S. (2008). Happiness, geography and the environment. Ecological Economics, 65(2), 386-396. doi:10.1016/j.ecolecon.2007.07.008

Brightlands. (2019). About Brightlands. Retrieved from Brightlands: https://www.brightlands.com/about-brightlands

Cameron, A., \& Trivedi, P. (2009). Microeconometrics using stata. Texas: Stata Press.

Carnevale, A., Smith, N., \& Melton, M. (2011). STEM: Science Technology Engineering Mathematics. Washington, DC: Georgetown University Center on Education and the Workforce.

CBS. (2016). Toelichting Wijk-en Buurtkaart 2014,2015 en 2016. Den Haag/Heerlen: CBS.

CBS. (2018). Bevolking op 1 januari; leeftijd, geboorteland en regio. Retrieved 2019, from CBS: https://opendata.cbs.nl/statline/\#/CBS/nl/dataset/70648ned/table?ts=1568719023013

CBS. (2019a). CBS. Retrieved from Bevolking; leeftijd, migratieachtergrond, geslacht en regio, 1 januari: https://opendata.cbs.nl/statline/\#/CBS/nl/dataset/37713/table?ts=1565099973107

CBS. (2019b). CBS Definitions Degree of Urbanisation. Retrieved from CBS: https://www.cbs.nl/engb/our-services/methods/definitions?tab=d\#id=degree-of-urbanisation 
CBS. (2019c). Bevolkingsontwikkeling; levend geborenen, overledenen en migratie per regio. Retrieved from CBS:

https://opendata.cbs.nl/statline/\#/CBS/nl/dataset/37259ned/table?ts=1568789666694

Chemelot. (2016). Visie Chemelot 2025: De meest competitieve en duurzame chemie- en materialensite van West-Europa. Sittard-Geleen: Chemel ot. Retrieved from https://www.chemelot.nl/visie

Chemelot. (2018). Chemelot. Retrieved from Chemel ot for today's future: https://www.chemelot.nl/homepage

Chemelot. (2019). Chemelot Facts and Figures. Retrieved from Chemelot for today's future: https://www.chemelot.nl/chemelot-en/facts-figures

Clark, E., Westergård-Nielsen, N., \& Kristensen, N. (2009). Economic satisfaction and income rank in small neighbourhoods. Journal of the European Economic Association 7(2-3):519-527, 7(23), 519-527. doi:10.1162/JEEA.2009.7.2-3.519

Clark, T., Lloyd, R., Wong, K., \& Jain, P. (2002). Amenities drive urban gro wth. Journal of Urban Affairs, 24(5), 493-515. doi:10.1111/1467-9906.00134

Creswell, J., \& Plano Clark, V. (2011). Designing and conducting mixed methods research. Thousand Oaks, California: Sage Publications.

Dahl, M., \& Sorensen, O. (2010). The migration of techincal workers. Journal of Urban Economics, 67(1), 33-45. doi:10.1016/j.jue.2009.09.009

Delken, E. (2008). Happiness in shrinking cities in Germany. A research note. Journal of Happiness Studies, 9, 213-218 . doi:DOI 10.1007/s10902-007-9046-5

Diener, E., Oishi, S., \& Lucas, R. (2003). Personality, culture, and subjective well-being: emotional and cognitive evaluations of life. Annual Review of Psychology, 54, 403-425. doi:10.1146/annurev.psych.54.101601.145056

Diener, E., Suh, E. M., Lucas, R. E., \& Smith, H. L. (1999). Subjective Well-Being: Three Decades of Progress. Psychological Bulletin, 125(2), 276-302. doi:10.1037/0033-2909.125.2.276

Dittmann, J., \& Goebel, J. (2010). Your House, Your Car, Your Education: The Socioeconomic Situation of the Neighborhood and its Impact on Life Satisfaction in Germany. Social Indicators Research, 96(3), 497-513. doi:10.1007/s11205-009-9489-7

Dolan, P., \& White, M. (2007). How can measures of subjective well-being be used to inform public policy? Perspectives on Psychological Science, 1, 71-85. doi:10.1111/j.17456916.2007.00030.x.

Easterlin, R. (1974). Does economic growth improve the human lot? Nations and households in economic growth, 89-125. doi:10.1016/B978-0-12-205050-3.50008-7

Etzkowitz, H., \& Leydesdorff, L. (1997). Universities and the global knowledge economy: A triple helix of university-industry-government relations. London: Cassell Academic. 
EuropeanParliament. (2015). Encouraging STEM studies. Labour market situation and comparison of practices targeted at young people in different MemberStates -Study. Brussels: DirectorateGeneral for Internal Policies of the Union (European Parliament). Retrieved from https://op.europa.eu/en/publication-detail/-/publication/125159ec-f256-4a9a-a690f9b6a84013af

Eurostat. (2019). Eurostat. Retrieved from NUTS - Nomenclature of territorial units for statistics: https://ec.europa.eu/eurostat/web/nuts/background

Ferrer-i-Carbonell, A., \& Frijters, P. (2004). How Important is Methodology for the estimates of the determinants of Happiness? The economic journal, 114(497), 641-659. doi:10.1111/j.14680297.2004 .00235

Florida, R. (2002a). The rise of the creative class. New York: Basic Books.

Florida, R. (2002b). The economicgeography of talent. Annals of the Association of American Geographers, 92(4), 743-755. doi:10.1111/1467-8306.00314

Florida, R. (2017). The New Urban Crisis. New York: Basic Books.

Florida, R., \& Gates, G. (2001). Technology and Tolerance: The importance of diversity to hightechnology growth. Washington DC: Brookings Institution, Center for Urban and Metropolitan Policy.

Florida, R., Mellander, C., \& Rentfrow, P. (2013). The happiness of cities. RegionalStudies, 613-627.

Frenkel, A., Bendit, E., \& Kaplan, S. (2013). Residential location choice of knowledge-workers: The role of amenities, workplace and lifestyle. Cities, 35, 33-41. doi:10.1016/j.cities.2013.06.005

Gieryn, T. (2000). A space for place in sociology. Annual Review of Sociology, 26, 463-496 . Retrieved from https://www.jstor.org/stable/223453

Glaeser, E., Gottlieb, J., \&Ziv, O. (2016). Unhappy cities. Journal of Labor Economics, 129-182.

Glaeser, E., Kolko, J., \& Saiz, A. (2001). Consumer city. Journal of Economic Geography, 1(1), 27-50. doi:10.1093/jeg/1.1.27

Greene, J., Caracelli, V., \& and Graham, W. (1989). Toward a Conceptual Framework for MixedMethod Evaluation Designs. Educational Evaluation and Policy Analysis, 11(3), 255-274. doi:10.2307/1163620

Harsanyi, J. (1982). Morality and the theory of rational behaviour. In A. S. (Eds.), Utilitarianism and beyond (pp. 39-63). Cambridge: Cambridge University.

Helliwell, J., \& Putnam, R. (2004). The social context of well-being. Philosophical Transactions of the RoyalSociety B: Biological Sciences, 359(1449), 1435-1446. doi:10.1098/rstb.2004.1522

Hilbrecht, M., Smale, B., \& Mock, S. (2014). Highway to health? Commute time and well being among Canadian adults. 56(2), 151-163. doi:10.1080/16078055.2014.903723 
Hooijen, I., \& Cörvers, F. (2015). Het aantrekken van kenniswerkers in een krimpgebied. Rooilijn, 48(4), 288-295. Retrieved from http://archief.rooilijn.nl/download?type=document\&identifier=586511

Jeanett, J.-P., \& Schreuder, H. (2015). From coal to biotech. The transformation of DSM with business schoolsupport. Berlin Heidelberg: Springer-Verlag.

Kahneman, D., Diener, E., \& Schwarz, N. (1999). Well-being: Foundations of hedonic psychology. New York: Russell Sage.

Kahneman, D., Krueger, A., Schkade, D., Schwarz, N., \& Stone, A. (2004). A Survey Method for Characterizing Daily Life experience: The Day Reconstruction Method. SCIENCE, 306(5702), 1776-1780. doi:10.1126/science. 1103572

Kingdon, G., \& Knight, J. (2007). Community, comparisons and subjective well-being in a divided society. Journal of Economic Behavior \& Organization, 64, 69-90 . doi:10.1016/j.jebo.2007.03.004

Kinossian, N. (2018). Planning strategies and practices in non-core regions: a critical response. European Planning Studies, 26(2), 365-375. doi:10.1080/09654313.2017.1361606

Knies, G. (2011). Income comparisons among neighbours and satisfaction in East and West Germany. Social Indicators Research, 106, 471-489. doi:10.1007/sl 1205-01 1-9818-5

Knies, G., Burgess, S., \& Propper, C. (2007). Keeping up with the Schmidt's - An Empirical Test of Relative Deprivation. Theory in the Neighbourhood Context. Berlin: SOEPpapers on Multidisciplinary Panel Data Research. doi:10.2139/ssrn.1096121

Kooij, H. (2015). Space for Innovation, Innovation in space. Nijmegen: Radboud Universiteit Nijmegen.

Kotkin, J. (2000). The new geography: How the digital revolution is reshaping the American landscape. New York: Random House.

Langdon, D. M. (2011). STEM: Good jobs now and for the future. Washington, DC: US Department of Commerce. Economics and Statistics Administration.

Langeweg, S. (2011). Mijnbouwen arbeidsmarkt in Nederlands-Limburg. Herkomst, werving, mobiliteit en binding van mijnwerkers tussen 1900 en 1965. Hilversum: Uitgeverij Verloren.

Leick, B., \& Lang, T. (2018). Re-thinking non-core regions: planning strategies and practices beyond growth. European Planning Studies, 26(2), 213-228. doi:10.1080/09654313.2017.1363398

Longhi, S. (2014). Cultural diversityand subjective well-being. IZA Journal of Migration, 3(13), 1-19.

Lorenz, O. (2018). Does commuting matter to subjective well-being? Journal of Transport Geography , 66, 180-199. doi:10.1016/j.jtrangeo.2017.11.019 
MaastrichtUniversity. (2019). Kennis-As Limburg. Retrieved from Maastricht University: https://www.maastrichtuniversity.nl/about-um/organisation/mission-strategy/kennislimburg

Mannheim, K. (1936/2015). Ideology and Utopia: An introduction to the sociology of knowledge. Eastford : Martino Fine Books.

Martinez-Fernandez, C., Wu, C., Schatz, L., Taira, N., \& Vargas-Hernández, J. (2012). The Shrinking Mining City: Urban Dynamics and Contested Territory. International Journal of Urban and Regional Research, 36(2), 245-206. doi:DOI:10.1111/j.1468-2427.2011.01094.x

Massey, D. (1995). Spatial Divisions of Labor: Social Structures and the Geography of Production. New York : Routlegde.

McCann, P. (2017). Urban futures, population ageing and demographic decline. Cambridge Journal of Regions, Economy and Society, 10, 543-557. doi:10.1093/cjres/rsx009

Medvedev, O., \& Landhuis, E. (2018). Exploring constructs of well-being, happiness and quality of life. PeerJ, 1-17. doi:10.7717/peerj.4903

MinistryofSocialDevelopment. (2003). Physicalenvironment. The social report. Wellington: Ministry of Social Development. Retrieved from http://socialreport.msd.govt.nz/2003/physicalenvironment/physical-environment.shtml

Morrison, P. (2007). Subjective well-being and the city. Social Policy Journal of New Zealand, 74-103.

Morrison, P. (2011). Local expressions of subjective well-being: The New Zealand experience. RegionalStudies, 1039-1058. doi:10.1080/00343401003792476

Morse, J., \& Niehaus, L. (2009). Mixed method design: Principles and procedures. Walnut Creek: Left Coast Press.

Musterd, S., \& Gritsai, O. (2013). The creative knowledge city in Europe: Structural conditions and urban policy strategies for competitive cities. European Urban and RegionalStudies, 20(3), 343-359. doi:10.1177/0969776412439199

Musterd, S., Bontje, M., \& Rouwendal, J. (2016). An introductory framework. In S. Musterd, M. Bontje, \&J. (. Rouwendal, Skills and cities: Implications of location preferences of highly educated workers for spatial development of metropolitan areas. (pp. Part I, chapter 1, 119). New York: Routlegde.

O'Leary, Z. (2010). The Essential Guide to Doing Your Research Project. London: Sage.

O'Brien, R. (2007). A caution regarding rules of thumb for variance inflation factors. Quality \& Quantity, 41, 673-690. doi:https://doi.org/10. 1007/s11135-006-9018-6

OECD. (2013). OECD Regions at a Glance 2013. Paris: OECD Publishing.

OECD. (2014). OECD Territorial Reviews: Netherlands 2014. Paris: OECD Publishing. 
OECD. (2017). Land-use Planning Systems in the OECD. Country Fact Sheets. Paris: OECD Publishing. doi:10.1787/9789264268579-en

Olsson, L., Gärling, T., Ettema, D., Friman, M., \& Fujii, S. (2013). Happiness and Satisfaction with Work Commute. Social Indicators Research, 111(1), 255-263. doi:10.1007/s11205-012-00032

ProvinceofLimburg. (2016). Structuurvisie Wonen Zuid-Limburg. Maastricht: Province of Limburg.

Rijksoverheid. (2019). Indeling gemeenten krimpregio's en anticipeerregio's per 1 januari 2019. Retrieved from Bevolkingsdaling:

https://www.rijksoverheid.nl/onderwerpen/bevolkingsdaling/documenten/publicaties/2019 /07/25/indeling-gemeenten-krimpregios-en-anticipeerregios-per-1-januari-2019

Schimmack, U., Oishi, S., Furr, M., \& Funder, D. (2004). Personality and Life Satisfaction: A FacetLevel Analysis. Personality and Social Psychology Bulletin, 30(8), 1062-1075. doi:10.1177/0146167204264292

Scott, A. (2006). Creative cities: conceptual issues and policy questions . Journal of Urban Affairs, 28(1), 1-17. doi:10.1111/j.0735-2166.2006.00256.x

Scott, A. (2010). Jobs or amenities? Destination choices of migrant engineers in the USA. Papers in RegionalScience, 89(1), 43-63. doi:10.1111/j.1435-5957.2009.00263.x|

Shields, M., \& Wheatley Price, S. (2005). Exploring the economic and social determinants of psychological well-being and perceived social support in England. Journal of the Royal Statistical Society, 168(3), 513-537. doi:10.1111/j.1467-985X.2005.00361.x

Shields, M., Wheatley Price, S., \& Wooden, M. (2009). Life satisfaction and the economic and social characteristics of neighbourhoods. Journal of Population Economics, 22(2), 421-443. doi:10.1007/s00148-007-0146-7

Shucksmith, M., Cameron, S., Merridew, T., \& Pichler, F. (2009). Urban-rural differences in quality of life across the European Union. Regional Studies, 43(10), 1275-1289. doi:10.1080/00343400802378750

Singelenberg, J., Goetgeluk, W., \& Jansen, S. (2011). The residential images method. In S. Jansen, H. Coolen, \& R. Goetgeluk, The Measurement and Analysis of Housing Preference and Choice (pp. 157-176). Dordrecht: Springer.

Sjaastad, L. (1962). The costs and returns of human migration. Journal of Political Economy, 80-93.

Sleutjes, B. (2013). The hard and soft side of European knowlegde regions. Highereducated location preferences (HELP-UVA VU). Amsterdam: Universiteit van Amsterdam.

Sleutjes, B. (2015). Woonvoorkeuren van kennismigranten. DEMOS, 4-7.

Soeters, J. H., Spoormans, H., \& Welten, R. (1990). Het nieuwe Limburg. Maastricht: Rutten/LeiterNypels. 
Sørensen, J. F. (2014). Rural-Urban differences in life satisfaction: Evidence from the European Union. RegionalStudies, 48(9), 1451-1466. doi:10.1080/00343404.2012.753142

Stutzer, A., \& Frey, B. (2008). Stress that doesn't pay: The commuting paradox. The Scandinavian Journal of Economics, 110(2), 339-366. doi:10.1111/j.1467-9442.2008.00542.x

Tiebout, C. (1956). A pure theory of local expenditures. Journal of Political Economy, 416-424.

Van Bussel, M., Denissen, C., Muskens, B., \& Kuijpers, A. (2016). Je zal er maarwonen. Ontwerpend onderzoek naar huisvesting van kenniswerkers in een krimpregio. Stein: buroStUB. Retrieved from http://kenniswerkersinlimburg.nl/wp-

content/uploads/2016/06/Rapport_KenniswerkersinLimburg_BuroSTUB.pdf

van Praag, B., Frijters, P., \& Ferrer-i-Carbonella, A. (2003). The anatomy of subjective well-being. Journal of Economic Behavior \& Organization , 51, 29-49.

doi:https://doi.org/10.1016/S0167-2681(02)00140-3

Veenhoven, R. (2012). Happiness: Also Known as "Life Satisfaction" and "Subjective Well-Being". In K. Land, A. Michalos, M. Sirgy, \& (eds), Handbook of Social Indicators and Quality of Life Research (pp. 63-77). Dordrecht: Springer.

Vossen, D., Sternberg, R., \& Alfken, C. (2019). Internal migration of the 'creative class' in Germany. RegionalStudies, 53(10), 1359-1370. doi:10.1080/00343404.2019.1566699

Wiechmann, T., \& Bontje, M. (2015). Responding to Tough Times: Policy and Planning Strategies in Shrinking Cities. European Planning Studies, 23(1), 1-11.

doi:https://doi.org/10.1080/09654313.2013.820077

Winters, J. (2017). Do Native STEM Graduates Increase Innovation? Evidencefrom U.S. Metropolitan Areas. Stillwater, Oklahoma: Economics Working Paper Series Department of Economics Oklahoma State University. 


\section{Appendix 1: Interview guide}

\begin{tabular}{|l|}
\hline Personal information \\
\hline Gender \\
\hline Age \\
\hline Born: \\
\hline Marital status: \\
\hline Children living at home: \\
\hline Type of job: \\
\hline Years working at the campus: \\
\hline
\end{tabular}

\begin{tabular}{|l|}
\hline Dwelling \& living environment \\
\hline Place of residence: \\
Rural - suburban - urban \\
\hline Dwelling type \& rental/own: \\
\hline Years in dwelling: \\
\hline Number of moves: \\
\hline Factors for choosing the current dwell ing: \\
\hline Factors for choosing the current living environment: \\
\hline Are you satisfied with your dwelling? \\
If not, what would you desire/wish? \\
\hline $\begin{array}{l}\text { (Demographics) How would you describe your living environment? (for example, quiet, busy, young, } \\
\text { old, poor, rich) }\end{array}$ \\
\hline Are you satisfied with your living environment? \\
If not, what would you desire/wish?
\end{tabular}

Amenities and facilities

Do you find it important to have amenities and facilities (such as a supermarket or GP) near (radius of $15 \mathrm{~min}$ ) home?

Why/why not?

Do you find it important to have a lot of amenities and facilities (swimming pool, museum, restaurants, and concerts) near home?

Why/why not?

Are you satisfied with the amenities and facilities in your living environment?

If not, why not? 
Distance

What transportation do you use to go to work?

What is your commute time (one way)?

Do you find the role of the commute distance important/satisfactory?

Why/why not?

Leisure time and personality

What are your hobbies?

What do you do in your spare/leisure time?

Do you participate in any associations (e.g. music, sports)?

If so, how often do you participate each week?

If not, why not?

Would you describe yourself as an introvert or extravert?

Why? 
STEM Non-STEM

(\%) (\%)

\begin{tabular}{|c|c|c|}
\hline \multicolumn{3}{|l|}{ Individual characteristics } \\
\hline Male & 89.5 & 76.9 \\
\hline Age in years (mean) & 44.4 & 50.7 \\
\hline Born in Limburg Province (NL) & 57.9 & 69.2 \\
\hline $\begin{array}{l}\text { Born elsewhere in the } \\
\text { Netherlands }\end{array}$ & 15.8 & 23.1 \\
\hline Born abroad & 26.3 & 7.7 \\
\hline $\begin{array}{l}\text { Low educational level } \\
\text { (vocational training) }\end{array}$ & 21.1 & $\mathrm{n} / \mathrm{a}$ \\
\hline $\begin{array}{l}\text { Medium educational level } \\
\text { (bachelor's) }\end{array}$ & 42.1 & 69.3 \\
\hline $\begin{array}{l}\text { High educational level (master's } \\
\text { or above) }\end{array}$ & 36.8 & 30.7 \\
\hline $\begin{array}{l}\text { Children living at interviewee's } \\
\text { home }\end{array}$ & 52.6 & 69.3 \\
\hline $\begin{array}{l}\text { Place characteristics } \\
\text { Distance }\end{array}$ & & \\
\hline Commute time is important & 78.9 & 92.3 \\
\hline $\begin{array}{l}\text { Commute time in minutes } \\
\text { (mean) }\end{array}$ & 23.7 & 25.3 \\
\hline Transportation to work is a car & 57.9 & 76.9 \\
\hline Transportation to work is a bike & 26.3 & 23.1 \\
\hline $\begin{array}{l}\text { Transportation to work is other } \\
\text { Amenities and facilities }\end{array}$ & 15.8 & $\mathrm{n} / \mathrm{a}$ \\
\hline $\begin{array}{l}\text { Basic amenities and facilities are } \\
\text { important }\end{array}$ & 94.7 & 92.3 \\
\hline $\begin{array}{l}\text { Urban amenities and facilities } \\
\text { are important }\end{array}$ & 26.3 & 23.1 \\
\hline Demographic composition & & \\
\hline $\begin{array}{l}\text { Lives in an average to wealthy } \\
\text { neighbourhood (own } \\
\text { perception) }\end{array}$ & 100 & 100 \\
\hline $\begin{array}{l}\text { Young to mixed age distribution } \\
\text { in neighbourhood (own } \\
\text { perception) }\end{array}$ & 94.7 & 61.5 \\
\hline $\begin{array}{l}\text { Cultural diversity in } \\
\text { neighbourhood (average to yes) } \\
\text { (own perception) } \\
\text { Living environment }\end{array}$ & 73.7 & 7.7 \\
\hline Home owner & 89.5 & 92.3 \\
\hline $\begin{array}{l}\text { Satisfied with living } \\
\text { environment } \\
\text { Urbanization level }\end{array}$ & 100 & 100 \\
\hline Urban living & 36.8 & 23.1 \\
\hline Suburban living & 31.6 & 23.1 \\
\hline Rural living & 31.6 & 53.8 \\
\hline Overall life satisfaction & 100 & 100 \\
\hline
\end{tabular}




\begin{tabular}{lll}
\hline $\boldsymbol{N}$ & 19 & 13 \\
\hline
\end{tabular}


Appendix 3: Summary and descriptive statistics of the survey respondents

\begin{tabular}{|c|c|c|c|c|c|c|c|c|}
\hline Variable & $\begin{array}{l}\text { STEM } \\
\text { mean }\end{array}$ & SD & Min & Max & $\begin{array}{l}\text { Non- } \\
\text { STEM } \\
\text { mean }\end{array}$ & SD & Min & Max \\
\hline \multicolumn{9}{|l|}{ Individual characteristics } \\
\hline Life satisfaction & 8,92 & 1,12 & 3 & 10 & 9,03 & 0,99 & 6 & 11 \\
\hline Age & 46,89 & 11 & 23 & 64 & 48,19 & 9,62 & 27 & 64 \\
\hline Age squared & 2320 & 998 & 529 & 4096 & 2414 & 900 & 729 & 4096 \\
\hline Extraversion, Big Five & 1,93 & 0,94 &,- 06 & 4,3 & 2,34 & 0,97 &,- 06 & 4,5 \\
\hline Satisfaction income & 8,78 & 1,46 & 0 & 10 & 8,87 & 1,44 & 0 & 10 \\
\hline Satisfaction social network & 9,01 & 1,13 & 3 & 10 & 9,04 & 1,21 & 4 & 10 \\
\hline Satisfaction health & 8,77 & 1,44 & 2 & 10 & 8,70 & 1,48 & 2 & 10 \\
\hline \multicolumn{9}{|l|}{ Place characteristics } \\
\hline \multicolumn{9}{|l|}{ Distance } \\
\hline Distance from home to work & 19,48 & 14,78 & 2,60 & 74,40 & 18,23 & 17,55 & 1,5 & 109 \\
\hline $\begin{array}{l}\text { Distance from home to the } \\
\text { nearest main road }\end{array}$ & 1,69 & 0,47 & 0,6 & 4 & 1,63 & 0,42 & 0,90 & 2,70 \\
\hline \multicolumn{9}{|l|}{ Amenities and facilities } \\
\hline Number of businesses & 4359 & 3255 & 475 & 18400 & 4188 & 3300 & 475 & 18400 \\
\hline $\begin{array}{l}\text { Average number of restaurants } \\
\text { and bars in a radius of } 1 \mathrm{~km} \\
\text { Demographic composition }\end{array}$ & 5,03 & 3,36 & 1,55 & 12,55 & 4,82 & 3,04 & 1,55 & 12,55 \\
\hline $\begin{array}{l}\text { Average annual income per } \\
\text { inhabitant in a municipality } \\
{[x 1,000]}\end{array}$ & 22,44 & 1,07 & 20,20 & 25,70 & 22,54 & 1,32 & 20,20 & 28,90 \\
\hline$\%$ cultural diversity & 10,18 & 3,37 & 4 & 24 & 10,06 & 2,93 & 4,50 & 16 \\
\hline$\%$ people aged 65 and over & 21,82 & 1,94 & 16 & 27 & 21,85 & 1,88 & 16 & 27 \\
\hline Number of inhabitants per km² & 1170 & 666 & 149 & 2546 & 1164 & 615 & 198 & 2546 \\
\hline \multirow[t]{2}{*}{$N$} & 258 & & & & 162 & & & \\
\hline & $61,43 \%$ & & & & $38,57 \%$ & & & \\
\hline
\end{tabular}

\begin{tabular}{lcc}
\hline Variable & $\begin{array}{c}\text { STEM } \\
\%\end{array}$ & $\begin{array}{c}\text { Non-STEM } \\
\%\end{array}$ \\
\hline Individual characteristics & & \\
Male & 87.6 & 71.6 \\
Partner & 84.9 & 88.3 \\
Dutch & 86.4 & 93.8 \\
Low educational level & 33.7 & 27.8 \\
Medium educational level & 40.3 & 45.7 \\
High educational level & 26.0 & 26.5 \\
Children living at home & 51.2 & 61.1 \\
Monthly expenses of dwelling <€400 & 20.5 & 13.6 \\
\hline
\end{tabular}




\begin{tabular}{lcc}
\hline$€ 400-€ 699$ & 34.5 & 27.8 \\
$€ 700-€ 999$ & 23.6 & 29.0 \\
$€ 1000-€ 1500$ & 17.4 & 22.2 \\
$>€ 1500$ & 3.9 & 7.4 \\
Place characteristics & & \\
Living urban & 28.7 & 24.7 \\
Living suburban & 30.2 & 32.7 \\
Living rural & 41.1 & 42.6 \\
No match between living preferences \& & 60.5 & 63.0 \\
actual residence & & \\
& & \\
$\mathbf{N}$ & 258 & 162 \\
& 61.43 & 38.57 \\
& & \\
\hline
\end{tabular}


Appendix 4: Full-model OLS and OP

\begin{tabular}{|c|c|c|}
\hline Life satisfaction & OLS & OP \\
\hline \multicolumn{3}{|l|}{ Control Variables } \\
\hline Age & $\begin{array}{l}0.0188 \\
(0.0617)\end{array}$ & $\begin{array}{l}0.00509 \\
(0.0708)\end{array}$ \\
\hline Age squared & $\begin{array}{l}-0.000188 \\
(0.000660)\end{array}$ & $\begin{array}{l}-6.07 e-05 \\
(0.000769)\end{array}$ \\
\hline Gender (female) & $\begin{array}{l}0.0301 \\
(0.204)\end{array}$ & $\begin{array}{l}0.0202 \\
(0.245)\end{array}$ \\
\hline Extraversion, Big Five & $\begin{array}{l}0.119 * * \\
(0.0572)\end{array}$ & $\begin{array}{l}0.144^{* *} \\
(0.0671)\end{array}$ \\
\hline Partner (yes) & $\begin{array}{l}0.243^{*} \\
(0.131)\end{array}$ & $\begin{array}{l}0.342^{*} \\
(0.182)\end{array}$ \\
\hline Nationality (Dutch) & $\begin{array}{l}0.0710 \\
(0.171)\end{array}$ & $\begin{array}{l}0.0542 \\
(0.225)\end{array}$ \\
\hline Medium education (ref.: low) & $\begin{array}{l}-0.0970 \\
(0.0890)\end{array}$ & $\begin{array}{l}-0.119 \\
(0.106)\end{array}$ \\
\hline High education & $\begin{array}{l}0.0277 \\
(0.131)\end{array}$ & $\begin{array}{l}0.0169 \\
(0.183)\end{array}$ \\
\hline Children living at home (yes) & $\begin{array}{l}-0.111 \\
(0.117)\end{array}$ & $\begin{array}{l}-0.165 \\
(0.125)\end{array}$ \\
\hline Monthly expenses dwelling €400-€699 (ref.: <€400) & $\begin{array}{l}0.0169 \\
(0.102)\end{array}$ & $\begin{array}{l}0.0503 \\
(0.137)\end{array}$ \\
\hline$€ 700$ to $€ 999$ & $\begin{array}{l}-0.0598 \\
(0.105)\end{array}$ & $\begin{array}{l}-0.112 \\
(0.128)\end{array}$ \\
\hline$€ 1000$ to $€ 1500$ & $\begin{array}{l}0.0537 \\
(0.0999)\end{array}$ & $\begin{array}{l}0.0717 \\
(0.128)\end{array}$ \\
\hline$>€ 1500$ & $\begin{array}{l}0.461^{* *} \\
(0.203)\end{array}$ & $\begin{array}{l}0.626^{* *} \\
(0.278)\end{array}$ \\
\hline Years living in dwelling & $\begin{array}{l}0.00733 \\
(0.00560)\end{array}$ & $\begin{array}{l}0.00835 \\
(0.00691)\end{array}$ \\
\hline Satisfaction with income & $\begin{array}{l}0.0926 \\
(0.0554)\end{array}$ & $\begin{array}{l}0.127^{*} \\
(0.0675)\end{array}$ \\
\hline Satisfaction with social network & $\begin{array}{l}0.236 * * * \\
(0.0526)\end{array}$ & $\begin{array}{l}0.297 * * * \\
(0.0648)\end{array}$ \\
\hline Satisfaction with health & $\begin{array}{l}0.188^{* * *} \\
(0.0412)\end{array}$ & $\begin{array}{l}0.229 * * * \\
(0.0404)\end{array}$ \\
\hline STEM worker & $\begin{array}{l}-1.033^{* * *} \\
(0.357)\end{array}$ & $\begin{array}{l}-1.407^{* * *} \\
(0.431)\end{array}$ \\
\hline Distance from home to work & $\begin{array}{l}-0.00384 \\
(0.00335)\end{array}$ & $\begin{array}{l}-0.00572 \\
(0.00414)\end{array}$ \\
\hline Distance from home to the nearest main road & $\begin{array}{l}0.342^{*} \\
(0.191)\end{array}$ & $\begin{array}{l}0.434^{*} \\
(0.249)\end{array}$ \\
\hline Number of businesses & $\begin{array}{l}-5.21 e-05 \\
(3.10 e-05)\end{array}$ & $\begin{array}{l}-6.12 e-05 \\
(3.87 e-05)\end{array}$ \\
\hline Number of restaurants and bars in a radius of $1 \mathrm{~km}$ & $\begin{array}{l}-0.0133 \\
(0.0236)\end{array}$ & $\begin{array}{l}-0.0191 \\
(0.0286)\end{array}$ \\
\hline Average annual income municipality & $\begin{array}{l}0.0281 \\
(0.0441)\end{array}$ & $\begin{array}{l}0.0266 \\
(0.0524)\end{array}$ \\
\hline Cultural diversity & -0.0473 & -0.0587 \\
\hline
\end{tabular}




\begin{tabular}{|c|c|c|}
\hline & $(0.0437)$ & $(0.0540)$ \\
\hline \multirow[t]{2}{*}{ People aged 65+ } & -0.000591 & -0.00607 \\
\hline & $(0.0618)$ & $(0.0775)$ \\
\hline \multirow[t]{2}{*}{ Population density } & -0.000184 & -0.000321 \\
\hline & $(0.000195)$ & $(0.000253)$ \\
\hline \multirow[t]{2}{*}{ Match living preferences and actual residential behaviour } & 0.213 & 0.277 \\
\hline & (0.186) & $(0.232)$ \\
\hline \multirow[t]{2}{*}{ Living in a suburban environment (ref.: urban) } & $-0.749 * * *$ & $-1.053^{* * *}$ \\
\hline & $(0.247)$ & $(0.321)$ \\
\hline \multirow[t]{2}{*}{ Living in a rural environment } & $-0.981 * *$ & $-1.369 * * *$ \\
\hline & $(0.396)$ & $(0.508)$ \\
\hline \multicolumn{3}{|l|}{ Interaction distance } \\
\hline \multirow[t]{2}{*}{ STEM worker*distance } & -0.00504 & -0.00646 \\
\hline & $(0.00582)$ & $(0.00691)$ \\
\hline \multirow[t]{2}{*}{ STEM worker*nearest main road } & $-0.722 * * *$ & $-0.940 * * *$ \\
\hline & $(0.245)$ & $(0.317)$ \\
\hline \multicolumn{3}{|l|}{ Interaction amenities } \\
\hline \multirow[t]{2}{*}{ STEM worker*number of businesses } & $-8.38 e-05$ & $-0.000121 *$ \\
\hline & $(5.18 e-05)$ & $(6.48 e-05)$ \\
\hline \multirow{2}{*}{ STEM worker*number of restaurants and bars } & 0.00819 & 0.0347 \\
\hline & $(0.0337)$ & $(0.0405)$ \\
\hline \multicolumn{3}{|l|}{ Interaction demographics } \\
\hline \multirow[t]{2}{*}{ STEM worker*average annual income municipality } & $0.321 * * *$ & $0.427 * * *$ \\
\hline & $(0.105)$ & $(0.130)$ \\
\hline \multirow[t]{2}{*}{ STEM worker*cultural diversity } & $0.132 * *$ & $0.167^{* *}$ \\
\hline & $(0.0527)$ & $(0.0650)$ \\
\hline \multirow{2}{*}{ STEM worker*people aged 65+ } & $-0.259 * * *$ & $-0.334 * * *$ \\
\hline & $(0.0939)$ & $(0.122)$ \\
\hline \multirow[t]{2}{*}{ STEM worker*population density } & 0.000559 & 0.000678 \\
\hline & $(0.000363)$ & $(0.000444)$ \\
\hline \multicolumn{3}{|l|}{ Interaction living preferences \& actual residence } \\
\hline \multirow[t]{2}{*}{ STEM worker*match } & -0.0636 & -0.0737 \\
\hline & (0.229) & $(0.267)$ \\
\hline \multirow[t]{2}{*}{ STEM worker*suburban } & $1.149 * * *$ & $1.563^{* * *}$ \\
\hline & (0.399) & $(0.465)$ \\
\hline \multirow[t]{2}{*}{ STEM worker*rural } & $1.656^{* * *}$ & $2.186^{* * *}$ \\
\hline & $(0.575)$ & $(0.703)$ \\
\hline \multirow[t]{2}{*}{ Constant } & $3.944 * *$ & \\
\hline & (1.698) & \\
\hline$N$ & 420 & \\
\hline$R^{2}$ - pseudo- $R^{2}$ & 0.376 & 0.1643 \\
\hline $\begin{array}{l}\text { Robust standard errors are in parentheses, and } \\
* * * p<0.01, * * p<0.05 \text {, and } * p<0.1 \text {. }\end{array}$ & & \\
\hline
\end{tabular}


Appendix 5: MEMs of the OP model for all values of the life satisfaction scale

\begin{tabular}{|c|c|c|}
\hline & MEMS & Std. error \\
\hline \multicolumn{3}{|c|}{ Distance from home to work } \\
\hline 3\#Non-STEMoccup & $6.10 e-07$ & $1.12 \mathrm{e}-06$ \\
\hline 3\#STEMoccup & $2.04 \mathrm{e}-06$ & 3.07e-06 \\
\hline 4\#Non-STEMoccup & $4.52 e-06$ & $5.13 e-06$ \\
\hline 4\#STEMoccup & 0.0000147 & 0.0000105 \\
\hline 5\#Non-STEMoccup & 0.0000476 & 0.0000486 \\
\hline 5\#STEMoccup & $0.0001498 * * *$ & 0.0000629 \\
\hline 6\#NOn-STEMoccup & 0.0001833 & 0.0002013 \\
\hline 6\#STEMoccup & $0.0005578 * *$ & 0.0002575 \\
\hline 7\#Non-STEMoccup & 0.000876 & 0.000882 \\
\hline 7\#STEMoccup & $0.0025305^{* *}$ & 0.0011366 \\
\hline 8\#NOn-STEMoccup & 0.000069 & 0.0001233 \\
\hline 8\#STEMoccup & -0.0000461 & 0.0002967 \\
\hline 9\#Non-STEMoccup & -0.0008101 & 0.0008176 \\
\hline 9\#STEMoccup & $-0.00224 * * *$ & 0.0009117 \\
\hline 10\#Non-STEMoccup & -0.000371 & 0.0003975 \\
\hline 10\#STEMoccup & $-0.0009687^{* *}$ & 0.0004417 \\
\hline \multicolumn{3}{|c|}{ Distance from home to the nearest main road } \\
\hline 3\#Non-STEMoccup & -0.0000645 & 0.0001141 \\
\hline 3\#STEMoccup & 0.0000854 & 0.0001297 \\
\hline 4\#Non-STEMoccup & -0.0004782 & 0.0003397 \\
\hline 4\#STEMoccup & 0.0006151 & 0.0004304 \\
\hline 5\#Non-STEMoccup & $-0.0050342 *$ & 0.0026958 \\
\hline 5\#STEMoccup & $0.0062591 * * *$ & 0.0026586 \\
\hline 6\#Non-STEMoccup & $-0.0193794^{* *}$ & 0.0099493 \\
\hline 6\#STEMoccup & $0.0233107^{* * *}$ & 0.0088441 \\
\hline 7\#Non-STEMoccup & $-0.0926125^{* *}$ & 0.0429847 \\
\hline 7\#STEMoccup & $0.1057504^{* * *}$ & 0.0260915 \\
\hline 8\#Non-STEMoccup & -0.0072927 & 0.0111098 \\
\hline 8\#STEMoccup & -0.0019267 & 0.0120837 \\
\hline 9\#Non-STEMoccup & $0.0856394^{* *}$ & 0.0425502 \\
\hline 9\#STEMoccup & $-0.0936102 * * *$ & 0.0288761 \\
\hline 10\#Non-STEMoccup & $0.0392221 * *$ & 0.0181304 \\
\hline 10\#STEMoccup & $-0.0404838 * * *$ & 0.0100863 \\
\hline \multicolumn{3}{|l|}{ Number of businesses } \\
\hline 3\#Non-STEMoccup & $1.05 e-08$ & $1.95 e-08$ \\
\hline 3\#STEMoccup & $2.93 e-08$ & $4.78 e-08$ \\
\hline 4\#Non-STEMoccup & 7.79e-08 & $5.25 e-08$ \\
\hline 4\#STEMoccup & $2.11 \mathrm{e}-07$ & $1.32 \mathrm{e}-07$ \\
\hline 5\#Non-STEMoccup & $8.21 \mathrm{e}-07^{*}$ & $4.68 \mathrm{e}-07$ \\
\hline 5\#STEMoccup & $2.15 \mathrm{e}-06^{* * *}$ & $8.20 \mathrm{e}-07$ \\
\hline 6\#NOn-STEMoccup & $3.16 \mathrm{e}-06^{*}$ & $1.83 e-06$ \\
\hline 6\#STEMoccup & $7.99 \mathrm{e}-06^{* * *}$ & $3.00 e-06$ \\
\hline 7\#Non-STEMoccup & $0.0000151^{* *}$ & $7.80 \mathrm{e}-06$ \\
\hline
\end{tabular}




\begin{tabular}{|c|c|c|}
\hline 7\#STEMoccup & $0.0000362^{* * *}$ & 0.0000105 \\
\hline 8\#Non-STEMoccup & $1.19 \mathrm{e}-06$ & $1.90 \mathrm{e}-06$ \\
\hline 8\#STEMoccup & $-6.60 e-07$ & $4.11 \mathrm{e}-06$ \\
\hline 9\#Non-STEMoccup & $-0.000014^{*}$ & 7.71e-06 \\
\hline 9\#STEMoccup & $-0.0000321 * * *$ & 0.0000111 \\
\hline 10\#NOn-STEMoccup & $-6.39 e-06^{*}$ & $3.45 e-06$ \\
\hline 10\#STEMoccup & $-0.0000139 * * *$ & $4.16 e-06$ \\
\hline \multicolumn{3}{|c|}{ Number of restaurants and bars in a radius of $\mathrm{km}^{2}$} \\
\hline 3\#Non-STEMoccup & $1.66 \mathrm{e}-06$ & 4.10e-06 \\
\hline 3\#STEMoccup & $-2.20 e-06$ & $6.27 e-06$ \\
\hline 4\#Non-STEMoccup & 0.0000123 & 0.0000302 \\
\hline 4\#STEMoccup & -0.0000159 & 0.0000367 \\
\hline 5\#Non-STEMoccup & 0.0001296 & 0.0002963 \\
\hline 5\#STEMoccup & -0.0001614 & 0.0003745 \\
\hline 6\#Non-STEMoccup & 0.0004989 & 0.0011226 \\
\hline 6\#STEMoccup & -0.0006012 & 0.0013203 \\
\hline 7\#Non-STEMoccup & 0.0023842 & 0.0054857 \\
\hline 7\#STEMoccup & -0.0027275 & 0.0058177 \\
\hline 8\#Non-STEMoccup & 0.0001877 & 0.0005291 \\
\hline 8\#STEMoccup & 0.0000497 & 0.0003315 \\
\hline 9\#Non-STEMoccup & -0.0022047 & 0.0050365 \\
\hline 9\#STEMoccup & 0.0024144 & 0.0052711 \\
\hline 10\#Non-STEMoccup & -0.0010097 & 0.0023621 \\
\hline 10\#STEMoccup & 0.0010441 & 0.0021712 \\
\hline \multicolumn{3}{|c|}{ Average annual income perinhabitants in a municipality } \\
\hline 3\#Non-STEMoccup & $-6.31 e-07$ & $8.23 e-06$ \\
\hline 3\#STEMoccup & -0.0000721 & 0.0001149 \\
\hline 4\#Non-STEMoccup & $-4.68 e-06$ & 0.0000609 \\
\hline 4\#STEMoccup & -0.0005194 & 0.0003265 \\
\hline 5\#Non-STEMoccup & -0.0000493 & 0.000643 \\
\hline 5\#STEMoccup & $-0.0052853 * * *$ & 0.0017738 \\
\hline 6\#Non-STEMoccup & -0.0001897 & 0.0024791 \\
\hline 6\#STEMoccup & $-0.0196842 * * *$ & 0.0067799 \\
\hline 7\#Non-STEMoccup & -0.0009065 & 0.0117361 \\
\hline 7\#STEMoccup & $-0.0892984^{* * *}$ & 0.0237326 \\
\hline 8\#NOn-STEMoccup & -0.0000714 & 0.0009329 \\
\hline 8\#STEMoccup & 0.0016269 & 0.0101731 \\
\hline 9\#Non-STEMoccup & 0.0008382 & 0.0108717 \\
\hline 9\#STEMoccup & $0.0790469 * * *$ & 0.0239265 \\
\hline 10\#NOn-STEMoccup & 0.0003839 & 0.0049832 \\
\hline 10\#STEMoccup & $0.0341855^{* * *}$ & 0.009728 \\
\hline \multicolumn{3}{|l|}{$\%$ of cultural diversity } \\
\hline 3\#Non-STEMoccup & 0.0000104 & 0.0000205 \\
\hline 3\#STEMoccup & -0.0000179 & 0.0000276 \\
\hline 4\#Non-STEMoccup & 0.0000771 & 0.000071 \\
\hline 4\#STEMoccup & -0.0001286 & 0.000083 \\
\hline
\end{tabular}




\begin{tabular}{|c|c|c|}
\hline 5\#Non-STEMoccup & 0.0008117 & 0.0006305 \\
\hline 5\#STEMoccup & $-0.001309 * * *$ & 0.0003764 \\
\hline 6\#Non-STEMoccup & 0.0031246 & 0.0025109 \\
\hline 6\#STEMoccup & $-0.0048749 * * *$ & 0.0017133 \\
\hline 7\#Non-STEMoccup & 0.0149321 & 0.0111124 \\
\hline 7\#STEMoccup & $-0.0221154 * * *$ & 0.0056772 \\
\hline 8\#NOn-STEMoccup & 0.0011758 & 0.001739 \\
\hline 8\#STEMoccup & 0.0004029 & 0.002547 \\
\hline 9\#Non-STEMoccup & -0.0138078 & 0.0101762 \\
\hline 9\#STEMoccup & $0.0195766^{* * *}$ & 0.0049207 \\
\hline 10\#Non-STEMoccup & -0.0063239 & 0.004799 \\
\hline 10\#STEMoccup & $0.0084663^{* * *}$ & 0.0025622 \\
\hline \multicolumn{3}{|l|}{ People aged 65> } \\
\hline 3\#Non-STEMoccup & $1.84 \mathrm{e}-06$ & 0.0000116 \\
\hline 3\#STEMoccup & 0.0000565 & 0.0000886 \\
\hline 4\#Non-STEMoccup & 0.0000136 & 0.0000817 \\
\hline 4\#STEMoccup & $0.0004072^{*}$ & 0.0002531 \\
\hline 5\#Non-STEMoccup & 0.0001433 & 0.0008588 \\
\hline 5\#STEMoccup & $0.0041437^{* * *}$ & 0.0014085 \\
\hline 6\#Non-STEMoccup & 0.0005518 & 0.0033519 \\
\hline 6\#STEMoccup & $0.0154324 * * *$ & 0.0049985 \\
\hline 7\#Non-STEMoccup & 0.0026369 & 0.015846 \\
\hline 7\#STEMoccup & $0.0700101^{* * *}$ & 0.0164331 \\
\hline 8\#Non-STEMoccup & 0.0002076 & 0.0013068 \\
\hline 8\#STEMoccup & -0.0012755 & 0.0080112 \\
\hline 9\#Non-STEMoccup & -0.0024383 & 0.0146819 \\
\hline 9\#STEMoccup & $-0.0619729 * * *$ & 0.0166882 \\
\hline 10\#Non-STEMoccup & -0.0011167 & 0.0067425 \\
\hline 10\#STEMoccup & $-0.0268015^{* * *}$ & 0.0065772 \\
\hline \multicolumn{3}{|l|}{ Population density } \\
\hline 3\#Non-STEMoccup & $4.23 e-08$ & $8.36 e-08$ \\
\hline 3\#STEMoccup & $-5.36 e-08$ & $1.06 e-07$ \\
\hline 4\#Non-STEMoccup & $3.14 \mathrm{e}-07$ & $3.06 e-07$ \\
\hline 4\#STEMoccup & $-3.86 e-07$ & $4.08 e-07$ \\
\hline 5\#Non-STEMoccup & $3.30 \mathrm{e}-06$ & $3.00 e-06$ \\
\hline 5\#STEMoccup & $-3.93 e-06$ & $4.15 e-06$ \\
\hline 6\#Non-STEMoccup & 0.0000127 & 0.00001 \\
\hline 6\#STEMoccup & -0.0000146 & 0.0000161 \\
\hline 7\#Non-STEMoccup & 0.0000607 & 0.0000492 \\
\hline 7\#STEMoccup & -0.0000663 & 0.0000675 \\
\hline 8\#Non-STEMoccup & $4.78 \mathrm{e}-06$ & $7.24 \mathrm{e}-06$ \\
\hline 8\#STEMoccup & $1.21 \mathrm{e}-06$ & $7.41 \mathrm{e}-06$ \\
\hline 9\#Non-STEMoccup & -0.0000562 & 0.0000456 \\
\hline 9\#STEMoccup & 0.0000587 & 0.0000627 \\
\hline 10\#Non-STEMoccup & -0.0000257 & 0.0000199 \\
\hline 10\#STEMoccup & 0.0000254 & 0.000026 \\
\hline
\end{tabular}




\begin{tabular}{|c|c|c|}
\hline \multicolumn{3}{|c|}{ Match preferences - actual residential behaviour } \\
\hline 3\#Non-STEMoccup & -0.0000386 & 0.0000885 \\
\hline 3\#STEMoccup & -0.0000315 & 0.0000564 \\
\hline 4\#NOn-STEMoccup & -0.0002874 & 0.0002789 \\
\hline 4\#STEMoccup & -0.0002285 & 0.0001944 \\
\hline 5\#Non-STEMoccup & -0.030561 & 0.0028531 \\
\hline 5\#STEMoccup & -0.0023486 & 0.00167 \\
\hline 6\#NOn-STEMoccup & -0.0119206 & 0.0094538 \\
\hline 6\#STEMoccup & -0.0088486 & 0.0057321 \\
\hline 7\#Non-STEMoccup & -0.0585788 & 0.0503853 \\
\hline 7\#STEMoccup & $-0.0410172 * *$ & 0.0207718 \\
\hline 8\#Non-STEMoccup & -0.0089754 & 0.0139235 \\
\hline 8\#STEMoccup & -0.0012231 & 0.0135437 \\
\hline 9\#Non-STEMoccup & 0.05585 & 0.0495258 \\
\hline 9\#STEMoccup & $0.0371002^{*}$ & 0.0206504 \\
\hline 10\#NOn-STEMoccup & 0.0270069 & 0.0256882 \\
\hline 10\#STEMoccup & 0.0165973 & 0.0118459 \\
\hline \multicolumn{3}{|c|}{ Living in a suburban environment (ref.: urban) } \\
\hline 3\#Non-STEMoccup & .0000578 & .0001132 \\
\hline 3\#STEMoccup & -0.0002419 & 0.0005092 \\
\hline 4\#Non-STEMoccup & 0.0004601 & 0.0002926 \\
\hline 4\#STEMoccup & -0.0014193 & 0.0018879 \\
\hline 5\#Non-STEMoccup & $0.0054099 * *$ & 0.0025685 \\
\hline 5\#STEMoccup & -0.0114683 & 0.0131776 \\
\hline 6\#Non-STEMoccup & $0.0238338 * * *$ & 0.0063591 \\
\hline 6\#STEMoccup & -0.0343596 & 0.0349388 \\
\hline 7\#Non-STEMoccup & $0.1500213^{* * *}$ & 0.0380511 \\
\hline 7\#STEMoccup & -0.1123725 & 0.0813355 \\
\hline 8\#NOn-STEMoccup & $0.1540804^{* *}$ & 0.0787732 \\
\hline 8\#STEMoccup & 0.0552042 & 0.0644109 \\
\hline 9\#NOn-STEMoccup & $-0.1797297 * * *$ & 0.0432332 \\
\hline 9\#STEMoccup & 0.0786708 & 0.0558221 \\
\hline 10\#Non-STEMoccup & $-0.1541336 * *$ & 0.0722976 \\
\hline 10\#STEMoccup & $0.0259866^{*}$ & 0.0146707 \\
\hline \multicolumn{3}{|c|}{ Living in a rural environment (ref.: urban) } \\
\hline 3\#Non-STEMoccup & 0.0002121 & 0.00039 \\
\hline 3\#STEMoccup & -0.000274 & 0.0005458 \\
\hline 4\#Non-STEMoccup & 0.0013859 & 0.0011185 \\
\hline 4\#STEMoccup & -0.0016701 & 0.0019558 \\
\hline 5\#Non-STEMoccup & $0.0130505^{*}$ & 0.0076138 \\
\hline 5\#STEMoccup & -0.0142962 & 0.0136505 \\
\hline 6\#Non-STEMoccup & $0.0470866 * *$ & 0.0210846 \\
\hline 6\#STEMoccup & -0.046046 & 0.0382604 \\
\hline 7\#Non-STEMoccup & $0.2271141^{* * *}$ & 0.0727924 \\
\hline 7\#STEMoccup & $-0.1753488 *$ & 0.0991321 \\
\hline 8\#Non-STEMoccup & $0.1161659 * *$ & 0.0556767 \\
\hline
\end{tabular}




\begin{tabular}{lll}
\hline 8\#STEMoccup & 0.032806 & 0.043992 \\
9\#Non-STEMoccup & $-0.2334592^{* * *}$ & 0.065061 \\
9\#STEMoccup & $0.14361^{*}$ & 0.0809892 \\
10\#Non-STEMoccup & $-0.17155^{* *} 58$ & 0.0780611 \\
10\#STEMoccup & $0.0612191^{*}$ & 0.0352574 \\
$\mathbf{N}$ & & \\
& 420 & \\
$* * * \boldsymbol{p}<\mathbf{0 . 0 1}, * * \boldsymbol{p}<\mathbf{0 . 0 5}, \boldsymbol{p}<\mathbf{0 . 1}$ & & \\
\hline
\end{tabular}

